\title{
The Prevalence and Validity of EBITDA as a Performance Measure
}

\author{
Jan BOUWENS \\ University of Amsterdam \\ Ties DE KOK \\ Tilburg University \\ Arnt VERRIEST \\ EDHEC Business School
}

August 2018

Working paper

\section{Abstract}

This study evaluates EBITDA as a financial performance measure and investigates the use of EBITDA in financial reporting. First, we take issue with recent comments that both the SEC and the IASB have levied against non-GAAP earnings numbers, and in particular EBITDA. While EBITDA allegedly provides an accurate reflection of the operations and abstracts from how assets are financed, we argue that (net) operating profit already provides this information without the necessity of making subjective adjustments. Also, our evidence suggests that EBITDA paints a rosy picture of the firm's profitability and cashgenerating ability. Next, using textual analysis, we investigate the prevalence of EBITDA in financial disclosures based on a large sample of 15,895 annual reports and 51,758 earnings releases from S\&P 1500 firms between 2005 and 2016. We find that $14.8 \%$ of sample firms disclose and emphasize EBITDA numbers. EBITDA disclosures modestly increase over time and tend to be rather sticky in nature. In our cross-sectional analyses, we find that, consistent with our hypotheses, EBITDA-reporting firms are smaller, more leveraged, more capital-intensive, less profitable and have longer operating cycles than non-EBITDA reporting firms. They also exhibit higher forecast errors and a higher likelihood of missing the analyst forecast benchmark. Additional tests further underscore the opportunistic nature of EBITDA disclosures as we find that these firm characteristics are more strongly associated with the disclosure of adjusted EBITDA measures, and less strongly associated with the disclosure of EBITA and EBIT. 


\section{Introduction}

EBITDA, or earnings before interests, taxes, depreciation and amortization, is a performance metric deployed for various purposes including corporate valuation, managerial performance and solvency measurement. The concept of EBITDA became popular with leveraged buyouts in the 1980s, primarily used to reflect the ability of a company to service debt. Over the subsequent years, EBITDA became popular in capital-intensive industries, in which expensive assets had to be written down over longer periods. Since then, EBITDA is frequently used both within a company and in its communication with shareholders as an alternative performance measure to net income, operating income, operating cash flow and free cash flow. ${ }^{1}$ Firms report EBITDA on a voluntary basis, as it involves a disclosure outside of U.S. GAAP (and IFRS), and is as such not audited or standardized. As of lately, an increase of press coverage and SEC scrutiny of EBITDA and other non-GAAP measures resulted from concerns about the increased use of these measures and their potentially misleading nature (e.g. Deloitte 2016). However, controversy about EBITDA and its validity has been around for a long time (e.g. Forbes 2003; Buffett 2002; Sherman and Young 2016). In our study we examine how the characteristics of EBITDA may lead stakeholders and regulators to oppose against the use of EBITDA. Some practitioners have argued that while EBITDA is presented as a profit number, its very use suggests that capital is free and freely renewable (Buffet 2002). Other experts have questioned EBITDA as a cash flow measure (Sherman and Young 2016). In this paper we take issue with these criticisms.

Our study serves four purposes. First, we shed light on the features of EBITDA as a measure of profitability and we evaluate its validity as an earnings and cash flow indicator. Second, we document how prevalent the use of EBITDA is in financial reporting. Third, we investigate which firms are more likely to disclose

\footnotetext{
${ }^{1}$ Operating cash flow is the net cash flow generated by the operations, which is shown on the cash flow statement. Typically, operating cash flow is assessed by adding depreciation, amortization and other noncash operating expenses (such as provisions for restructuring) and subtracting any increases in net working capital. Free cash flow is cash flow from operations less net investments in noncurrent operating assets. This number is equal to net dividends to shareholders plus the net payments to debt holders and debt issuers (Penman 2013).
} 
and emphasize EBITDA. Fourth, we compare determinants of EBITDA disclosure with alternative and related concepts including adjusted EBITDA, EBITA and EBIT. To serve these purposes, we employ a sample containing all available annual reports (10-K's) and earnings announcements from firms belonging to the S\&P 1500 index for the period 2005 to 2016.

The conclusions of this study can be summarized as follows. Our validity analysis suggests it is not unequivocally clear that EBITDA provides additional information on a firm's financial position, be it its profitability, cash-generating ability, liquidity risk or credit risk. Many value-relevant items are left out of the EBITDA calculation, rendering it less reflective of a firm's economic performance. In addition, when comparing EBITDA with alternative measures of earnings and cash flow, we find that EBITDA is usually the highest number. Therefore, EBITDA seems a suitable metric to disclose when management wants to show a better picture of firm performance. In this sense, our analysis supports the concerns levied by regulators and standard setters.

Descriptive evidence shows that in $24.8 \%$ of annual reports and $17.8 \%$ of press releases with earnings announcements EBITDA is mentioned at least once. We find that $14.8 \%$ of annual reports and $16.5 \%$ of earnings releases contains three or more EBITDA references. We find that the use of EBITDA in annual reports increases over time from $6.6 \%$ in 2005 to $23.5 \%$ in 2016 . The number of firms that start disclosing EBITDA outweighs the number of firms that decide to stop disclosing EBITDA. The probability that a firm discloses EBITDA in the next year, provided that it discloses EBITDA in the current year, is about $80 \%$.

Results from our cross-sectional analyses show that EBITDA-reporting firms differ systematically from firms that do not report EBITDA. Consistent with the notion that large, visible and reputed firms are less likely to engage in disclosures which may attract scrutiny and negative attention from regulators and the business press, we find that EBITDA-reporting firms are significantly smaller and show larger analyst forecast errors than firms which never mention EBITDA in their financial disclosures. Consistent with the notion that managers may use EBITDA as a means to window-dress performance, we find that more capital- 
intensive firms and higher leveraged firms are more likely to provide EBITDA disclosures. As EBITDA does not take into account investment expenses and interest expenses, capital-intensive and highly indebted firms have EBITDA numbers that are considerably higher than net or operating income. In line with this result, we also find that EBITDA-disclosing companies are more likely to have missed the analyst forecast benchmark of earnings than non EBITDA-reporting ones. Next, less profitable firms are more likely to emphasize EBITDA in their earnings announcements. Consistent with the prediction that managers talk about EBITDA to avert the attention from lower operating cash flows, we find that firms with larger increases in working capital and longer operating cycles are more likely to focus on EBITDA.

We supplement these findings with three sets of important additional tests. A first relevant extension of our empirical analyses is that we document the relation between firm characteristics and EBITDA disclosures in a changes specification. Specifically, we show that firms start (stop) disclosing EBITDA when becoming smaller (bigger), less (more) profitability, more (less) levered and more (less) capital intensive. In a second set of additional tests, we investigate the intensity of EBITDA disclosures by counting the number of times it is mentioned. Results show that, even when only considering firms that mention EBITDA at least once, it is the smaller, more leveraged and more capital intensive firms that emphasize EBITDA more strongly. The third set of additional analyses considers the determinants of disclosures related to EBITDA. We find strong evidence that adjusted EBITDA measures, labelled "Adjusted EBITDA" and EBITDAR, are much more likely to be disclosed in annual reports and earnings announcements by smaller and less profitable firms as well as by firms with more tangible and intangible assets and more debt on their balance sheets. These results hold when only considering EBITDA reporting firms, serving as an indication for the opportunistic nature of adjusted EBITDA disclosures. Finally, we investigate determinants of EBITA (or, EBITDA minus depreciation) and EBIT (or, operating income before tax) disclosures and find different results. Although leverage continues to be a significant determinant of the likelihood of EBIT or EBITA disclosure, we no longer find an impact of firm size, analyst forecast errors, profitability and working capital requirements. Interestingly, intangible asset size, determining the level of amortization expense but not 
depreciation expense, is positively associated with the likelihood of EBITA disclosures, but not EBIT disclosures.

This paper contributes to the literature in three relevant ways. First, and foremost, our study adds to the broad and growing literature on non-GAAP disclosures, as well as to the studies within the non-GAAP literature that focus on EBITDA. Although it serves as one of the most prominent non-GAAP disclosures, in fact, very few studies have explicitly focused on EBITDA. D'Souza, Ramesh and Chen (2010) and Rozenbaum (2018) are the notable exceptions. In contrast to these two studies, we are to the best of our knowledge the first to explicitly and extensively focus on the properties of EBITDA. As such, our study enhances our understanding of the concept of EBITDA as a non-GAAP financial disclosure. Moreover, we describe empirically how EBITDA compares with other performance measures and show detailed descriptive evidence on the prevalence and persistence of EBITDA disclosures for a large sample of firms. While D'Souza, Ramesh and Chen (2010) mainly emphasize the potential benefits of EBITDA as a measure allowing for more comparability across companies, we highlight the potential negative implications of employing EBITDA. Specifically, we put its validity as an earnings or cash flow measure to the test. As such, we also provide relevant input for the debate on the legitimacy of EBITDA and for the increasing concerns regulators have regarding non-GAAP measures, complementing the assertions of D'Souza, Ramesh and Chen (2010).

In a related study, Rozenbaum (2018) finds that EBITDA use potentially comes at a cost. EBITDAdisclosing firms over-invest in capital and documents systematic costs involved in using EBITDA in executive compensation contracts. Next to providing a descriptive discussion of EBITDA, our study extends Rozenbaum (2018) in three manners. First, as we report that smaller, less reputed, higher levered and more capital-intensive firms and firms with longer operating cycles are more likely to emphasize EBITDA in their disclosures, we do find indications of opportunistic motives explaining EBITDA disclosures. Rozenbaum (2018), in contrast, finds little evidence of EBITDA being disclosed opportunistically. Second, next to the probability of EBITDA being mentioned in financial reports, we also 
consider the intensity of EBITDA disclosures. Third, unlike Rozenbaum (2018), we also test which firm characteristics determine the probability of adjusted EBITDA disclosures, and EBIT and EBITA disclosures. These findings enhance our understanding of the negative implications of employing EBITDA in corporate performance evaluation as we find more indications of opportunistic disclosure behavior for adjusted EBITDA measures and less of such behavior for EBIT and EBITA. Our results also add to Isidro and Marques (2015) who for a set of large European firms investigate the effect of country-level factors on non-GAAP disclosures provided by managers in earnings releases. In our study, we investigate a similar research question, with a few important differences. First, we only focus on US data which does not allow considering country differences, but does provide us with a much larger and homogenous dataset. Second, we only focus on one specific non-GAAP disclosure item, which makes our study narrower but allows for a more detailed analysis of EBITDA-related disclosures. Finally, we contribute to Guillamon-Saorin, Isidro and Marques (2017) who document that managers attempt to distort investors' perceptions of performance when non-GAAP disclosures are of a lower quality. As these researchers do not explicitly focus on EBITDA, our findings of more opportunistic behavior in case of adjusted EBITDA figures and less of such behavior for EBIT and EBITA disclosures, are very much consistent with their conclusions and extend their empirical findings.

Second, our study complements the findings of the studies by Liu, Nissim and Thomas $(2002 ; 2007)$. These researchers investigate the valuation properties of a set of different value drivers, including earnings, cash flow and EBITDA. They find that forward earnings, followed by historical earnings outperform EBITDA and cash flow as measures of intrinsic firm value. In a recent paper, Nissim (2017) compares the ability of EBITA to explain market valuations with the ability of EBIT and EBITDA to do so, motivated by the increasing magnitude of amortization charges in the last decades. He finds that, although EBITDA outperforms EBIT and EBITA in most cases, the difference between EBITDA and EBITA has decreased over the last three decades. Also, and most importantly, he concludes that each of these three measures of operating performance have failed to predict stock returns over the last seven years in a consistent manner. 
Our results corroborate both of these studies in a number of ways. First, we provide an explanation for why EBITDA is found by Liu, Nissim and Thomas (2002) to be an inferior performance metric compared to net income. Second, information on which type of firms are emphasizing EBITDA in their disclosures may provide an indication in which cases EBITDA is a better or worse measure of intrinsic value. Another related study is $\mathrm{Li}$ (2016) who shows that EBITDA is less useful than net income in explaining credit risk. Yet, covenants in debt contracts often require firms to report EBITDA numbers. For instance, Demerjian and Owens (2016) show in their sample 76\% of their sample define interest coverage as EBITDA/Interest expense. Our study corroborates Li (2016) by explaining the potential caveats when relying on EBITDA for, in this case, the assessment of credit risk.

Third, our findings provide insight on how managers decide to report on their firm's performance to outsiders, contributing to the broad literature on voluntary disclosure and its determinants (e.g. Raffournier 1995; Depoers 2000; Botosan and Plumlee 2002; Bushman, Piotroski and Smith 2004; Prencipe 2004; Botosan and Stanford 2005; Garcia-Meca and Sanchez-Ballesta 2010; Verriest, Gaeremynck and Thornton 2013). One conclusion in this literature is that larger and more reputed firms provide more voluntary disclosures. Our study is unique in the sense that it considers a voluntary piece of disclosure, EBITDA, but one that does not necessarily provide better information to investors. Our findings are consistent with those documented in this literature. On the one hand, we find that EBITDA provides a distorted picture of a firm's true performance. On the other hand, we document that firms that do not disclose EBITDA are significantly larger, more profitable and have a better credit quality. These firms presumably refrain from disclosing EBITDA because it does not incrementally inform investors on the firm's fundamental value.

The remainder of the paper is organized as follows. Section 2 provides an overview of the non-GAAP literature and motivates our study. Section 3 evaluates EBITDA as a performance measure and compares it with alternative measures. Section 4 outlines our hypotheses. Section 5 describes the sample and provides descriptive statistics on the prevalence of EBITDA disclosures. Section 6 provides regression analyses. Section 7 concludes. 


\section{Literature and Motivation}

The literature on non-GAAP disclosures is large and still expanding. A recent study of Black, Christensen, Ciesielski and Whipple (2018) provides a coherent review of the academic literature and gives insights on what we have learned on non-GAAP disclosures after two decades of work. One stream of studies in this area documents that non-GAAP earnings disclosed by the management provide incremental information about future firm performance and firm value relative to GAAP earnings (e.g., Bhattacharya, Black, Christensen and Larson, 2003). These findings are mainly concentrated in areas where the underlying GAAP earnings are less informative (Lougee and Marquardt, 2004). For instance, a recent study by Leung and Veenman (2018) shows that non-GAAP earnings disclosures of loss firms provide incremental information to investors.

Another stream of studies finds that at least some managers disclose non-GAAP earnings in an opportunistic fashion. Kolev, Marquadt and McVay (2008) report that many non-GAAP exclusions are associated with future performance. Doyle, Lundholm and Soliman (2003) show that a trading strategy based on earnings excluding certain expenses and accruals yields inferior results compared to a trading strategy based on GAAP earnings. Bradshaw and Sloan (2002) find that, over time, the increased use of non-GAAP metrics coincides with an increased incidence of special items. Moreover, managers may employ these exclusions in non-GAAP information to meet earnings benchmarks such as analysts' forecasts or the profit-loss threshold, as demonstrated in prior studies by Lougee and Marquardt (2004), Black and Christensen (2009) and Isidro and Marques (2015). The study of Isidro and Marques (2015) examines the effect of institutional and economic country factors on non-GAAP disclosures provided by managers. They document that managers are more likely to use non-GAAP measures to meet or beat earnings benchmarks that GAAP earnings would miss. They find stronger evidence in countries with larger equity markets, stronger legal efficiency and better investor protection. In a related paper, Guillamon-Saorin, Isidro and Marques (2017) investigate the market's reaction to the disclosure of non-GAAP earnings measures that are combined with high impression management. They document that, although non-GAAP measures can be informative to 
investors, the non-GAAP adjustments are more persistent when they go along with more impression management. The authors conclude from these findings that managers do behave opportunistically when disclosing non-GAAP earnings and attempt to distort investors' perceptions of firm performance.

In addition, we often find the relevant financial press debating the usefulness of non-GAAP measures up to the point where it raises the question whether these measures are disclosed to window-dress firm performance, including the performance of loss firms (e.g., Lahart, 2016). As of recently, non-GAAP earnings measures have received critique from regulators as well. In 2016 both the SEC (WSJ, March, 2016) and the IASB (WSJ, July, 2016) have raised objections against firms presenting non-GAAP earnings, including EBITDA, in their financial statements. The tolerance of the IASB and SEC of firms reporting EBITDA and EBITDA-like numbers seems to have decreased. Following up on his speech "Performance reporting and the pitfalls of non-GAAP metrics" held at Annual Conference of the European Accounting Association (Hoogervorst, 2016), Hans Hoogervorst chairman of the IASB rejected in July 2016 the very use of EBITDA in financial statements (WSJ, July, 2016): "however, not all non-standard accounting terms deserve to be rigorously defined." EBITDA is an inherently misleading measure that Mr. Hoogervorst said he would not want to define. "Depreciation and amortization are very real costs and I don't think they should be left out of the analysis," he added. The comments of the SEC convey the same sentiment. In March 2016 the SEC asserted that it considered regulation to prevent firms from presenting non-GAAP numbers. Ms. White warned “... your CFO, they love the non-GAAP measures because they tell a better story..." The concern raised by the SEC is that firm managers may use and define EBITDA resourcefully so as to over-present performance. Other than providing a contribution to the academic literature, our study is motivated by these recent critiques.

In this study, we specifically focus on EBITDA as a non-GAAP financial disclosure. With a few exceptions including D'Souza, Ramesh and Chen (2010) and Rozenbaum (2018), EBITDA has not been subject to an explicit and detailed investigation, even though it is widely considered in practice. EBITDA is frequently used as a performance measure in the business press, is increasingly used in executive compensation 
contracts (Smith and Stradley 2010) and used in debt covenants in lending agreements (Chava and Roberts 2008). Proponents of EBITDA often present it as a measure that provides for a quick and convenient means to assess a firm's ability to pay back interest and debts, or a measure that reflects the "cash generating ability" of a firm. Some financial analysis text books qualify debt-to-EBITDA as a solvency ratio arguing that it captures the ability to fulfill future debt obligations. ${ }^{2}$ The alleged value of EBITDA may lie in that it provides for a generalizable (one-size fits all) accounting number that summarizes (1) the firm's profitability, (2) cash flow, and (3) credit quality (ability to service debt). Indeed, to arrive at EBITDA, the preparer adds back depreciation and amortization, which are noncash expense items of the current fiscal period and do not affect current cash flow. According to some, adding interests and taxes back makes the metric more comparable across firms (D’Souza, Ramesh and Chen 2010). Before studying determinants of EBITDA disclosures, in the next section we investigate the properties of EBITDA as a measure of firm performance and shed light on the above-mentioned critiques.

\section{Evaluating EBITDA as a measure of firm performance}

\subsection{EBITDA lies Outside of GAAP and IFRS}

EBITDA is not defined and standardized in US GAAP or IFRS. As a consequence, a pro-forma earnings number like EBITDA may appear as an unaudited number in the financial statements which also affects its credibility (Ball 1989; Ball, Jayaraman and Shivakumar 2012). Despite objections of regulators, firms often include and exclude items at will. ${ }^{3}$ Firms can mitigate some concerns by reconciling EBITDA with the GAAP number of net income. However, even if the number is reconciled, the use of the non-GAAP number may still detract or deprive investors from relevant information. Sherman and Young (2016) argue that the

\footnotetext{
${ }^{2}$ We are not aware of any financial analysis text books that consider EBITDA as a key profitability measure.

${ }^{3}$ Examples of such decisions include: "Do we include special items such as restructuring expenses and legal provisions or not?"; "Do we add back impairment charges or not?"; "Since we add back interest expense, do we subtract interest income or not?"; "Do we subtract dividend income or not?" etc.
} 
danger of EBITDA and other non-GAAP measures is that they are usually idiosyncratic, and be noncomparable across business and even from year to year within the same firm.

\subsection{EBITDA as a measure of (operating) cash flow}

Some proponents consider EBITDA an indicator of operating cash flow. For instance, Sherman and Young (2016) note that EBITDA is highly popular among private equity investors “... because it's thought to provide a quick proxy for the amount of cash flow available to service debt." At first sight, EBITDA can indeed be considered as a cash flow measure. Similar to how operating cash flow is assessed in the cash flow statement, depreciation and amortization, many firms' most relevant operating noncash expense items, are added back to earnings. However, for many firms EBITDA is not close to cash flow for two reasons. First, interest and tax expenses involve a clear and important cash outflow, yet they are added back to earnings to produce an EBITDA number. It is not unequivocally clear why some cash flow elements are added back and others not. Based on the findings in existing literature it would appear that interests (e.g., Sengupta 1998) and taxes (e.g., Laux 2013) constitute relevant cash outflows. One could argue that interests, a nonoperating item, need to be added back to assess operating cash flow. Tax expense is more dubious as it constitutes both a cash outflow and an operating item. Second, and often overlooked by practitioners, EBITDA does not take into account the capital and cash required to fund a firm's operating activities, which does influence operating cash flow. ${ }^{4}$ EBITDA starts with "earnings" and nowhere in its

\footnotetext{
${ }^{4}$ The difference between earnings and cash flow lies at the heart of this discussion. An earnings number should not contain any cash flows that are reported in accruals as this would violate the relations underlying the basic accounting equation where earnings represent an element of equity, and where earnings are defined as: cash flows plus change in accruals over the relevant fiscal period. Take, for instance, a credit sale: earnings increase when the sales contract is signed between buyer and seller, as revenues are recognized at that very point in time. These revenues are recorded as a positive change in accruals. Cash flows will not change until the client has paid his dues. The selling firm records the sales on credit as an accrual (accounts receivable) on the balance sheet. Consequently, until the client pays the amounts outstanding, the seller needs to find capital to bridge this gap in its operating cycle. Put differently, the seller needs to ensure having an alternative access to cash in order to fulfill its own, perhaps more timely, duties such as payments to employees and suppliers. So, when assessing a firm's operating cash flow, any increases in current operating assets (such as inventories and accounts receivable) need to be subtracted from earnings to get to this period's cash flow. This is exactly what is happening in the cash flow statement. In short, we conclude that EBITDA is very much different from (operating) cash flow.
} 
calculation are changes in working capital addressed. Acknowledging working capital requirements is highly relevant for cash flow analyses and liquidity risk purposes, and even more so for firms with long cash conversion or long operating cycles.

\subsection{EBITDA as a measure of (operating) earnings}

Next, we consider how accurately EBITDA captures economic performance of a company and compare it with earnings. From a valuation standpoint, one can raise objections against ignoring interest, taxes and depreciation and amortization. First, the literature suggests that each of these items are relevant to the users of financial statements when assessing the value of a security. See, for instance, on interest relevance: Sengupta (1998) and Christensen, Lee and Walker (2009); on tax relevance: Hanlon and Heitzman (2010) and Laux (2013); on depreciation relevance: Beaver and Ryan (2000) and Kang and Zhao (2010). Second, these three items differ substantially from one another in nature: Interest expense is a cash nonoperating expense; tax expense is a cash operating expense; depreciation and amortization are both operating, but noncash expenses.

Interest. Proponents of EBITDA claim that exclusion of interest expenses is necessary to render the measure comparable with companies that are financed differently. While this is in itself an accurate observation, users have access to measures to achieve exactly the same purpose within the GAAP framework. Nissim and Penman (2001) argue for the use of net operating profit (or, operating profit after tax). This metric is that earnings number the company would realize in case it is fully financed with equity, i.e. making abstraction of how management decides to finance the operations. Li (2016) observes that EBITDA is less useful in explaining credit risk than bottom-line earnings. EBITDA-based covenants are often chosen to make the performance measure less sensitive to capital expenditures. In our analyses, we calculate net operating profit by re-calculating the amount of tax that the company would have paid had interest deduction been impossible. Net operating profit provides investors with a clean measure of operating profitability. ${ }^{5}$

\footnotetext{
${ }^{5}$ We refer to Easton, McAnally, Sommers and Zhang (2015) for a detailed discussion.
} 
Tax. Proponents of pretax measures often argue to add back tax expense because tax treatment differs across regimes and industries, and some firms have more ability to lower tax charges than others. EBITDA also ignores tax expenses. However, taxes usually are a highly relevant operating expense. Taxes recur every year and form a substantial expense for most companies. Moreover, tax liabilities must always be settled. Therefore, it is debatable on whether investors are better served with a pre rather than post tax measure. If, for some reason (for instance for comparability purposes) one would like to have an operating profitability measure before tax, almost all firms provide an item in the income statement labelled: 'operating income'. ${ }^{6}$ Again, more appropriate alternatives than EBITDA are available.

Depreciation and amortization. EBITDA adds back depreciation and amortization, often with the argument that these are irrelevant expense items or items prone to managerial discretion. Yet, there are reasons for why depreciation and amortization expenses appear in the income statement. They constitute real economic expenses. Capital is not free and not freely renewable. Buffet (2002, p. 14) commented on EBITDA in the following terms "After September 11th, training for commercial airlines fell, and today it remains depressed. However, training for business and general aviation, our main activity, is at near-normal levels and should continue to grow. In 2002, we expect to spend \$162 million for 27 simulators, a sum far in excess of our annual depreciation charge of $\$ 95$ million. Those who believe that EBITDA is in any way equivalent to true earnings are welcome to pick up the tab." This comment suggests that the accrual-based operating income number reflects the economic course of events more accurately than EBITDA. Adding back depreciation does little to inform investors of how depreciation relates to the investments made over the period, while net operating profit does provide such a number (Nissim and Penman, 2001).

\subsection{EBITDA versus Alternative Performance Measures}

\footnotetext{
${ }^{6}$ Alternative labels of operating income include 'operating profit', 'profit before financial result', 'EBIT' and 'earnings before interest and taxes'.
} 
Our previous validity check indicates that EBITDA mostly serves as a hybrid construct in between operating earnings and cash flows. However, given its hybrid nature, it cannot capture either of these concepts accurately. In the remainder of this section, we describe empirically how EBITDA differs from earnings and cash flows. We draw data from Compustat, consider all US stock-listed firms between 1988 and $2016 .^{7}$ The total sample contains 162,626 firm-year observations. We assess 17 ratios in three categories. The earnings-based ratios (1-8) break down in three types: net income, net operating profit and operating income (before tax). The cash flow-based category (9-14) comprises ratios based on free cash flow and operating cash flow. The last category consists of EBITDA ratios (15-17). Within each category, we use different scalers to control for sensitivity. For instance, net income is scaled by sales, assets and equity giving rise to three widely used profitability ratios: ROS, ROA and ROE. Net operating profit is scaled by sales and net operating assets (NOA).

In Table 1 Panel A we calculate median values for the full sample, the S\&P 500 and the DOW 30. EBITDAbased ratios persistently surpass any of the other ratios, in every subsample. Moreover, the extent to which EBITDA ratios exceed other measures is large and significant. Operating profit before tax and operating cash flow ratios are at least $4 \%$ of sales, $4 \%$ of assets and $7 \%$ of NOA lower than equivalent EBITDA ratios. The median firm in the $\mathrm{S} \& \mathrm{P} 500$ realized an after-tax operating return of $12.55 \$$ and an operating cash inflow of $19.20 \$$ for every $100 \$$ invested in its net operating assets. These number are far below the 27.32 \$ of EBITDA per $100 \$$ invested. When focusing on the free cash flows, we notice that the median DOW 30 firm attains a margin of $7.91 \%$, in big contrast to the EBITDA margin of $23.3 \%$.

In Table 1 Panel B we construct quartiles based on ROE, Net operating profit margin and Operating cash flow on assets of the S\&P 500 sample. For each quartile, we calculate the median of EBITDA/Sales, EBITDA/Total Assets and EBITDA/NOA. We find that the EBITDA ratios are much higher than any of the three other measures, for all quartiles. More importantly, we notice that EBITDA ratios display a

\footnotetext{
${ }^{7}$ Before 1988, cash flow statements are generally not available. Also, we exclude financial firms (SIC 6000-6999).
} 
favorable outlook of firm performance compared to what earnings and cash flows show. For the quartile with the lowest ROE, we only find positive EBITDA ratios. Results generally show that EBITDA exceeds the alternative metrics for all firms. For instance, firms in the second quartile of net operating profit margin display a median EBITDA margin of $12.66 \%$ compared to an operating profit margin of $5.57 \%$.

In Table 1 Panel $\mathrm{C}$ we show the proportion of firms for which EBITDA outweighs net operating profit, gross profit, free cash flow and operating cash flow. EBITDA exceeds net operating profit for almost all firms. ${ }^{8}$ EBITDA even surpasses gross profit, sales minus cost of sales, for $13 \%$ (14\%) of the total sample (S\&P 500). EBITDA exceeds free cash flow for $70 \%$ of the total sample, for $87 \%$ of S\&P 500 and for $89 \%$ of DOW 30 firms. EBITDA exceeds operating cash flow for two thirds of the total sample, for $85 \%$ of S\&P 500 and for $90 \%$ of DOW 30 firms.

Collectively, these descriptive findings indicate that EBITDA exceeds most conventional earnings and cash flow metrics. Therefore, it may serve as an ideal number for management to emphasize in case it wants to overstate firm performance. Anecdotal evidence shows that EBITDA is indeed a widely used metric by both managers and other finance professionals, although far from all firms disclose and comment on their EBITDA. The next section formally describes our predictions regarding which firms are more likely to emphasize EBITDA and which are not, followed by our model design and regression analyses.

\section{Hypothesis Development}

The inclination of managers to overstate their results has been documented in the literature. Bowen, Davis and Matsumoto (2005) and Israeli (2015) demonstrate that managers present their investments opportunistically. Barth, Gow and Taylor (2012) show that many firms are reluctant to report stock-based compensation as an expense item. Many managers continue to use and emphasize such numbers in an attempt to affect investors' reading of the firm's financial condition (WSJ, August 2016). Our previous

\footnotetext{
${ }^{8}$ For the entire sample, EBITDA is lower than net operating profit for $7 \%$ of firms. Although at first sight EBITDA must by construction exceed net operating profit, this is not necessarily the case because of a negative tax expense (e.g. a tax refund).
} 
discussion indicates that EBITDA disclosures can be interpreted by investors as lower quality disclosures and an attempt by the management to window-dress the firm's performance. Moreover, EBITDA has drawn recent criticism from the regulators such as the SEC and is often times negatively looked upon in the business press (e.g. Forbes 2003). For these reasons, it is not straightforward whatsoever to consider EBITDA as a "boilerplate" disclosure to show company performance.

First, we test whether firms with a richer and higher-quality information environment are less likely to engage in EBITDA disclosures. Firms with more visibility stand a better reputation to defend. They usually face more scrutiny and monitoring than smaller firms. More reputed and transparent firms typically have more to lose from opportunistic disclosures, or disclosures that are considered to be weak by investors. To capture a firm's information environment, we use firm size and analyst forecast accuracy. Larger firms are more visible, better reputed and face more monitoring than small firms. For firms with a better information environment, it is typically easier for analysts to forecast future earnings. Therefore, we predict that larger firms and firms with higher forecast accuracy are less likely to disclose and emphasize EBITDA in their disclosures, in order not to give the impression they exaggerate or obfuscate true firm performance. We therefore have the following first hypothesis:

H1: EBITDA-disclosing firms are smaller and have lower analyst forecast accuracy than firms which do not disclose EBITDA.

Managers of firms with lower profitability than peers and firms with a lower expected profitability have higher incentives to provide information to investors that suggests the firm's future outlook still is favorable and sufficiently profitable. One strategy managers may have is to disclose non-GAAP information which improves the outlook of the firm's current and future performance. Our previous section has identified EBITDA as particularly suited for this purpose, as EBITDA most of the times exceeds other metrics such as operating profit or operating cash flow. If EBITDA is indeed applied as a disclosure tool to provide a 
positive impression of profitability, we expect firms with lower current and anticipated profitability to be more likely to disclose EBITDA as it serves them better. Therefore, our second hypothesis is:

H2: EBITDA-disclosing firms exhibit lower current and expected profitability than firms which do not disclose EBITDA.

Next, we consider the three items that EBITDA makes abstraction of, depreciation (and amortization) expense, interest expense and tax expense, which are added back to net income. We predict that more capital intensive firms are more likely to emphasize and disclose EBITDA. This hypothesis hinges on two principal arguments. First, managers are expected to be more likely to use EBITDA as a tool to window-dress performance when there is a bigger wedge between operating income (or EBIT) and EBITDA. Firms with more long-term assets on their balance sheet typically have higher amounts of depreciation and amortization expenses. EBITDA disclosures are expected to have a larger impact on investor's expectations when the items that are added back to net income constitute larger amounts. There is also a second potential effect. To the extent that managers engage in overinvestment in their firm's operations, they may attempt to obfuscate these investment activities by emphasizing EBITDA instead, which is unaffected by investment actions (Li 2016). Therefore, we formulate the following hypothesis:

H3a: EBITDA-disclosing firms have more tangible and intangible assets than firms which do not disclose EBITDA.

Firms that finance themselves with substantially larger portions of debt as opposed to equity are also expected to be more inclined to disclose EBITDA. Our arguments run along the same lines as for depreciation expense. Firms with higher amounts of debt typically have higher amounts of interest expense. Also, firms that over-invest in operating assets and finance these with debt have higher interest expenses. When levels of debt and interest expenses are high, the utility for the manager to enhance the performance outlook of the company and the incentive to disguise over-investment activity is higher. Therefore, we 
predict that firms with, ceteris paribus, higher amounts of interest expense are more likely to disclose and emphasize EBITDA numbers in their financial communication. The next hypothesis is:

H3b: EBITDA-disclosing firms have higher amounts of interest expense and higher leverage than firms which do not disclose EBITDA.

Next, EBITDA also counts back tax expense. However, we do not expect that firms disclosing EBITDA necessarily have higher tax expenses. In hypothesis 2 we expect these firms to be less profitable. As a consequence, their pre-tax numbers may be lower. We expect these two opposite effects to counterbalance each other. Therefore, we state the following hypothesis in the null form:

H3c: EBITDA-disclosing firms do not have a different tax expense rate than firms which do not disclose EBITDA.

In addition, we consider the difference between operating cash flow and EBITDA. When reconciling earnings with operating cash flow, typically increases in working capital, measured as changes in operating current assets minus changes in operating current liabilities, are subtracted. Positive working capital requirements negatively affect cash flow, but not net income nor EBITDA. Firms with longer operating cycles typically need to invest more in working capital (such as receivables and inventories), especially when they exhibit growing sales. For these firms, EBITDA is much higher than operating cash flow and free cash flow. Their managers are expected to find greater utility in disclosing EBITDA than firms with shorter operating cycles. Our fourth hypothesis is:

H4: EBITDA-disclosing firms are more likely to have longer operating cycles and higher working capital requirements than firms which do not disclose EBITDA.

In our final hypothesis, we look into whether earnings expectations have been missed or not. Lougee and Marquardt (2004) and Isidro and Marques (2015) find evidence consistent with the notion that firms failing to meet analyst forecasts are more likely to exclude items in their non-GAAP earnings and to disclose non- 
GAAP earnings in general. Since EBITDA is a financial figure that in most cases outperforms any conventional cash flow or earnings number, it makes it a suited item to disclose and emphasize in case management wants to deviate attention from bad news. To capture bad news, we investigate analyst forecast errors on one-year ahead earnings per share numbers. In particular, we conjecture that firms which have missed analyst expectations are more likely to disclose and emphasize EBITDA than firms that have met or beaten the analyst forecast. Our fifth and final hypothesis is:

H5: EBITDA-disclosing firms are more likely to have missed analyst forecasts than firms which do not disclose EBITDA.

\section{Empirical evidence on the prevalence of EBITDA in financial reporting}

\subsection{Sample selection}

We search for EBITDA disclosures in 8-K and 10-K EDGAR filings for firms belonging to the S\&P 1500 for the period 2005-2016. ${ }^{9}$ In total, we are able to extract 22,354 annual reports and 57,911 press releases containing earnings announcements. On each of these reports we conduct a word search on the term "EBITDA". All company data is downloaded from WRDS Compustat. After matching the reports with Compustat and removing observations with missing data on market capitalization, total assets, sales, net income, book value of equity, capital expenditure, R \& D and cash, we have a sample of 15,895 annual reports and 51,758 earnings releases which we use for our main regression analyses.

\subsection{Descriptive statistics}

We find that on average $14.8 \%$ of sample firms mention EBITDA at least three times in their annual report. About one fourth, 24.8\%, mention EBITDA at least once, while 7.4\% mention EBITDA ten times or more. Further, we find that $54.1 \%$ of firms (or 1,307 firms) never disclose EBITDA in any of the years between

\footnotetext{
${ }^{9}$ The S\&P 1500 contains all large and medium-sized stock listed companies in the US and is an often used index and sample in practice and academic research. Our sample includes all firms that have at some point been in the S\&P 1500 in this period.
} 
2005 and 2016, while 9.1\% (or 219 firms) mention EBITDA in every annual report. 137 firms disclose EBITDA at least three times in every year between 2005 and 2016. Table 2 Panel A provides the percentage of firms in each Fama-French industry that report EBITDA three times or more.

Next, we evaluate the prevalence of EBITDA disclosure in annual reports over time. Figure 1 shows that EBITDA disclosures have increased significantly from 2005, in which year $6.6 \%$ of firms mentioned EBITDA, to 2016, in which EBITDA has been disclosed by $33.8 \%$ of the sample. Thus, we find a significant increase in the use of EBITDA, despite its dubious nature and criticism from regulators. The regulators' scrutiny could also be a consequence of the increased EBITDA disclosures. Interestingly, we notice the biggest increases in EBITDA reporting during the years 2008-2010, around the financial crisis.

Next, we investigate the stickiness of EBITDA disclosures. The probability that a firm disclosing EBITDA in the current year still does so in the next fiscal period ranges between $80 \%$ (2005-2006) and 93\% (20112012). These probabilities lie between $77 \%$ and $86 \%$ for two-year ahead EBITDA disclosure and between $74 \%$ and $81 \%$ for three-year ahead EBITDA disclosure. Further, Table 2 Panel B shows that on average 26 firms stop reporting on EBITDA while 48 firms start to report it. For instance, in 200619 firms stop reporting EBITDA, while 25 others initiate EBITDA disclosure. In most years, the number of firms starting to disclose EBITDA is larger than the number of firms stopping to report it, with 2009 as the year in which this difference was largest. We conclude that EBITDA disclosures are quite pervasive over time.

\section{Empirical evidence on determinants of EBITDA disclosures}

\subsection{Model Design}

To test the five hypotheses, we employ the following regression specification: 


$$
\begin{aligned}
\text { EBITDA }_{i t}= & \text { Firm Size }_{i t} \alpha_{1}+\text { ROA }_{i t} \alpha_{2}+\text { Leverage }_{i t} \alpha_{3}+\text { Market to Book }_{i t} \alpha_{4} \\
& + \text { Sales Growth }_{i t} \alpha_{5}+\text { Capital Intensity }_{i t} \alpha_{6}+\text { Intangibles }_{i t} \alpha_{7} \\
& + \text { Interest Exp }_{i t} \alpha_{8}+\text { Tax Rate }_{i t} \alpha_{9}+{\text { Change in } W C_{i t} \alpha_{10}} \\
& + \text { Forecast Miss }_{i t} \alpha_{11}+\text { Forecast Error } \\
& \\
& + \text { Capex }_{i t} \alpha_{15}+\text { Cash }_{i t} \alpha_{13}+R \& D_{i t} \alpha_{14}
\end{aligned}
$$

The dependent variable, EBITDA $\mathrm{it}_{\mathrm{it}}$, is an indicator variable equal to 1 if firm $i$ in year $t$ discloses EBITDA three times or more in the $10-\mathrm{K}$ annual report, and zero otherwise. We choose three disclosures or mentioning of EBITDA, to make sure we capture firms that explicitly talk about their EBITDA. In additional analyses, we rerun our tests setting the criterion at 1,2 or 10 mentioning(s) of EBITDA. Results are qualitatively the same. In equivalent tests, we test for EBITDA disclosures in earnings announcement reports. We create an indicator equal to 1 if EBITDA is mentioned at least once in the earnings announcement report. ${ }^{10}$ Using different criteria for these tests again do not qualitatively change our inferences.

To test Hypothesis 1, we include the log of market capitalization, measured as the stock price multiplied by the number of shares outstanding, as our main indicator of Firm Size. As alternatives, we consider the log of sales and assets. We expect a negative coefficient. To test Hypothesis 2, we introduce ROA, return on assets, measured as net income on total assets. We also measure Market to Book, which is a conventional indicator of (future) growth opportunities. We predict the coefficient on these variables to be negative. Sales Growth, the percentage increase in annual revenues, is also added as a measure for (current) growth. However, the coefficient on Sales Growth may go either way. Firms with increasing sales have higher working capital requirements. In Hypothesis 4 we predict these firms to be more likely to disclose EBITDA. Therefore, when considering sales growth as a measure of both growth opportunities and working capital

\footnotetext{
${ }^{10}$ We set the criterion at 1 instead of 3 counts, as earnings announcements are usually much shorter than 10-K annual reports. Results are very similar when setting the criterion at 3 counts.
} 
requirements, under Hypothesis 2 we expect it to be negative while under Hypothesis 4 we expect it to be positive. Capital Intensity, measured by property, plant and equipment, and Intangibles, intangible assets (excluding goodwill) are both scaled by total assets and introduced to test Hypothesis 3a. We predict to find positive coefficients on Capital Intensity and Intangibles. Hypothesis $3 \mathrm{~b}$ is tested by including Leverage, measured as total debt scaled by assets, and Interest Exp, the interest expense number stemming from the income statement scaled by sales. We expect positive coefficients on these variables. Tax Rate is the effective tax rate calculated by the actual tax expense scaled by pretax income. Tax Rate is included to test Hypothesis $3 c$ and we have no prediction for the sign of its coefficient. To test our hypothesis 4 , we include the changes (or growth) in working capital, Change in WC, measured by operating current assets minus operating current liabilities, scaled by total assets. Change in $W C$ is positive for firms with higher working capital requirements. We predict to find a positive coefficient. To test hypothesis 5, we introduce Forecast Miss, an indicator variable equal to 1 if the company has missed the last consensus analyst forecast and zero if the it has met or beaten the forecast. Finally, we include Forecast Error, measured as the absolute difference between actual EPS and forecasted EPS scaled by lagged stock price, as an alternative indicator for the quality of the firm's information environment to test Hypothesis 1 . We expect a negative coefficient on Forecast Error. ${ }^{11}$

We also include corporate cash holdings, Cash, research and development expense $(R \& D)$ and capital expenditures, Capex, as additional controls, each of them scaled by assets. All variables are measured in the current fiscal period. ${ }^{12}$ All variables are winsorized at the top and bottom percentile, except for Firm Size. We also introduce industry effects, based on two-digit SIC codes, and year effects. ${ }^{13}$ We test this specification as a Probit-model and cluster standard errors by firm.

\footnotetext{
${ }^{11}$ Forecast Miss and Forecast Error are only included in the specifications where we test the disclosure of EBITDA in the annual reports, but not when testing the earnings announcement reports. It is too difficult to accurately determine the analyst forecast consensus just before the announcement date for all observations.

${ }^{12}$ In robustness tests, we also use lagged values of the independent and control variables in regression analyses to explain EBITDA disclosure in the current fiscal period. Results and very similar and qualitatively the same.

${ }^{13}$ In additional tests, we include annual growth in GDP per capita as a macroeconomic control variable. In line with the findings of Figure 1 of an increase in EBITDA disclosures around the financial crisis, we find a negative coefficient
} 


\subsection{Univariate analysis}

Table 3 shows differences between EBITDA-reporting and non-EBITDA-reporting firms. Consistent with the notion that firms with a better information environment firms are less likely to engage in disclose EBITDA, we find that EBITDA-reporting firms are significantly smaller and have higher forecast errors. Also, EBITDA-reporting firms are less profitable (lower ROA) and more likely to be loss firms. However, EBITDA-reporting firms do not have lower growth opportunities or lower current growth rates. Next, we find that EBITDA-reporting firms are more capital intensive, carry more debt on their balance sheet and pay more interests. Tax rates are not different. EBITDA-reporting firms have longer operating cycles and higher increases in working capital, and they are more likely to have missed the earnings benchmark set by analyst forecasts.

\subsection{Multivariate analysis: main specification}

Table 4 shows results from our main regression model. In Panel A, the dependent variable is an indicator for EBITDA disclosure in annual reports. In the first specification we include Firm Size, ROA and Leverage as test variables. We find that EBITDA-reporting firms are significantly smaller. The coefficient on Firm Size remains significantly negative throughout all specifications and turns out to be the most important predictor of the probability that a firm discloses EBITDA. In specification 5, we find a positive coefficient on Forecast Error, indicating that firms with a lower quality information environment are more likely to disclose EBITDA. For these reasons, we conclude to find strong evidence for Hypothesis 1 . We find that EBITDA is mainly disclosed by smaller, less visible and less reputed firms, in line with the notion that these firms face less scrutiny from investors and less pressure to provide high-quality disclosures. $R O A$ does not carry a significantly negative coefficient. Market-to-Book and Sales Growth are not significant, implying that we are unable to find evidence for Hypothesis 2. However, we notice that Leverage always

on GDP growth when testing for EBITDA disclosures in annual reports. We do not find a significant coefficient when testing for EBITDA disclosures in earnings announcements. 
carries a significantly positive coefficient, consistent with Hypothesis $3 \mathrm{~b}$. Also, when in specification 3 Interest Exp is included, we find a positive coefficient, even if Leverage continues to be in the model. Testing Hypothesis 3a, we include Capital Intensity and Intangibles. We find a modestly positive coefficient on Capital Intensity and a strong positive coefficient on Intangibles, consistent with the notion that more capital intensive firms have more utility from providing EBITDA numbers to the market since depreciation and amortization expense is large. We fail to find a significant effect of Tax Rate, in line with Hypothesis $3 \mathrm{c}$ which was stated in the null. Next, in specification 4 we consider the Changes in WC to test Hypothesis 4. Consistent with the idea that firms with longer operating cycles and higher operating investment needs may enhance the outlook of their operating cash flows by disclosing EBITDA, we find a significantly positive coefficient on Changes in WC. Further, we find a modestly positive coefficient on Forecast Miss, consistent with Hypothesis 5 that firms missing the analyst forecast benchmark are more likely to focus on EBITDA. Finally, our model is found to be significant in explaining the probability of a firm disclosing EBITDA, as the R-square values are high given the large number of observations. Also, unreported statistics show that the model classifies $85.5 \%$ of observations correctly.

In Panel B of Table 4, the dependent variable is an indicator for EBITDA disclosure in press releases containing earnings announcements. We consider the equivalent tests for earnings releases as highly important to our study for two reasons. First, the number of observations is almost four times larger, as there are multiple earnings announcements per fiscal period. Second, earnings announcements are a more focused and timely disclosure tool for firms to communicate with investors about their performance. Annual reports contain many other disclosure items, such as governance and social issues, while press releases on earnings announcements are focused on profitability. In line with Hypothesis 1, we again find a strong negative effect of Firm Size on the likelihood of EBITDA disclosure. However, we now also find evidence consistent with Hypothesis 2 as $R O A$ also carries a negative coefficient. Consistent with Hypothesis 3 a and Hypothesis 3b, we find positive coefficients on Capital Intensity, Intangibles, Leverage and Interest Exp. The coefficient on Change in WC is not significant (p-value is 0.13 ). However, closer analysis shows that 
this is due to the large correlation this variable has with Sales Growth, which consistently shows a positive coefficient in this table. This finding is consistent with the notion that firms with increasing sales have higher working capital requirements and therefore more likely to disclose EBITDA (Hypothesis 4). Indeed, when we omit Sales Growth from the model in specification (4), we find a positive coefficient on Change in WC (p-value of 0.08 ). The model classifies $82.3 \%$ of observations correctly.

In what follows, we discuss the results from four important additional analyses that we execute to further understand how and which firm traits relate to EBITDA disclosures.

\subsection{Changes specification}

In a first set of additional tests, we verify the robustness of our main results by testing whether the firm characteristics that are significant in our main analyses (firm size, leverage, capital intensity, working capital requirements and missing analyst forecasts in particular) also explain changes in EBITDA disclosure. To be able to do so, we require an estimation technique that allows us to test whether firm factors explain the variance that remains after the persistence over time in EBITDA disclosures has been controlled for. To meet this requirement, we run the same regression including the lagged value of the dependent variable, which is an equivalent estimation procedure as running a regression of changes on changes (see, for instance, Opler, Pinkowitz, Stulz and Williamson 1999). Specifically, we add EBITDA in Prior Year to the model. EBITDA in Prior Year is an indicator variable equal to one if the firm has disclosed EBITDA in the previous fiscal period. This procedure constitutes as a particularly powerful test to investigate which firm characteristics explain whether a firm discloses EBITDA in the current year given that it has not done so in the previous year, or vice versa.

Table 5 Panel A presents results for EBITDA disclosures in annual reports. We immediately notice a strong increase in the predictive power of the model attaining R-square values around 55\%. This should not come as a surprise given that our descriptive statistics have already shown that EBITDA disclosures are quite sticky over time. However, the predictability is not (close to) 1 , so there remains considerable variation to be explained in the probability that a firm discloses EBITDA provided that it has (or has not) disclosed 
EBITDA previously. Most important for our study is that we again find strong evidence for our Hypotheses 1, 3 and 4. Specifically, we continue to find significantly negative coefficients on Firm Size and positive coefficients on Leverage in all specifications. Although the amount of tangible assets does not seem to matter that much anymore, we continue to find that firms with higher Intangibles have a higher likelihood of disclosing EBITDA. Next, we find a strongly positive coefficient on Change in $W C$, in line with Hypothesis 4. Finally, the coefficient on Forecast Miss is weakly positive, in line with Hypothesis 5.

Table 5 Panel B shows results for changes in EBITDA disclosures in earnings announcements. In this case, we test for the probability that a firm discloses EBITDA in the current earnings release, controlling for whether the firm has disclosed EBITDA in the previous earnings announcement or not. We find negative coefficients on Firm Size, consistent with Hypothesis 1. Equally important is that we find a negative and highly significant coefficient on $R O A$, in line with Hypothesis 2. Firms with lower ROA have a significantly higher probability of starting to disclose EBITDA, while firms with higher ROA have a higher probability of stopping to report on EBITDA. Leverage carries a significantly positive coefficient in each specification, in line with Hypothesis 3b. In Specifications (3) and (4) we find convincing evidence for Hypotheses 3b: Capital Intensity and Intangibles have positive and significant coefficients. Interestingly, we also find that increasing sales (Sales Growth) and increasing working capital (Change in WC) are positively associated with the likelihood of EBITDA disclosure.

\subsection{Intensity of EBITDA disclosures}

Until now we have investigated the likelihood of EBITDA disclosures in annual reports (3 counts or more) and earnings announcement reports (1 count or more). However, using a binary indicator as the dependent variable does not allow us to investigate determinants of the intensity or prevalence of EBITDA disclosures. Therefore, we introduce EBITDA Count, which equals the number of times EBITDA is mentioned. As this number is highly positively skewed, we measure EBITDA Count as the log of (1+ number of EBITDA disclosures). As many firms never mention EBITDA even once, EBITDA Count equals zero for many observations. Therefore, we test the model as a Tobit specification, with left censoring at zero. 
Results on EBITDA intensity are summarized in Table 6. We test EBITDA Count in the annual reports (Panel A) and in earnings announcement reports (Panel B). In specifications (1)-(4) of Panel A all firms are included. In line with Hypothesis 1 we find that larger firms and firms with lower forecast errors have fewer EBITDA mentions. We do not find evidence for Hypothesis 2, but we do for Hypotheses $3 \mathrm{a}$ and $3 \mathrm{~b}$ as the coefficients on Leverage, Interest Exp, Capital Intensity and Intangibles all carry a positive sign. Consistent with Hypotheses 4 and 5, we find that firms with larger increases in working capital and firms missing the analyst forecast benchmark are emphasizing EBITDA more than other firms. In specifications (5) and (6), we only consider firms that disclose EBITDA at least once. In other words, we test for EBITDA intensity given that the firm mentions EBITDA. We test these specifications as a regular OLS model. We find that firms with higher leverage, higher interest expenses and higher capital intensity emphasize EBITDA more than others. Firm Size and Change in WC are no longer significant. ${ }^{14}$

When testing the intensity of EBITDA disclosures in earnings announcements (Panel B), in specifications (1)-(3) we find significant coefficients on Firm Size, ROA, Leverage, Capital Intensity, Intangibles and Interest Exp, in line with expectations under Hypotheses 1, 2 and 3. When only considering EBITDA disclosing firms in specifications (4) and (5), we also find evidence consistent with Hypothesis 1: smaller firms emphasize EBITDA more strongly, even among EBITDA disclosers. Further, we find that firms with more intangibles, higher leverage and higher interest expense are also mentioning EBITDA more frequently than others. ${ }^{15}$

\subsection{Adjusted EBITDA disclosures}

The focus so far has been on the likelihood and prevalence of EBITDA disclosures. In our two remaining tests, we investigate the disclosure of alternative, but related to EBITDA, disclosures. In a first set of

\footnotetext{
${ }^{14}$ In specifications (4) and (5) we do not include the Forecast Miss and Forecast Error as we lose too many observations. When including them, the results do not materially change and these two forecast variables are not significant.

${ }^{15}$ Leverage carries a significantly positive coefficient in specification (4). Its effect is subsumed by the entrance of Interest Exp in specification (5).
} 
additional tests, we investigate the likelihood of firms mentioning “Adjusted EBITDA" and "EBITDAR". Adjusted EBITDA usually adds further items to earnings such as stock-based compensation expense, leading to an even higher number than EBITDA. Adjusted EBITDA is mentioned at least once in the annual report by $8.9 \%$ of the firms. EBITDAR most often stands for EBITDA before rental expense on a tangible asset item. EBITDAR is disclosed by $1.1 \%$ of companies. We test which firm characteristics predict the disclosure of adjusted EBITDA and EBITDAR. Results are summarized in Table 7.

We consider Adjusted EBITDA and EBITDAR as comparable measures in nature and consider them separately (in specifications (1) and (2)) and combined (in specifications (3)-(6)). The first four specifications focus on disclosures in the annual report and the latter two on earnings announcement reports. In specifications (1), (2), (3) and (5) all firms are considered and in specifications (4) and (6) only EBITDA disclosing firms enter the sample. ${ }^{16}$ From specifications (1) to (3) we see that firms disclosing Adjusted EBITDA or EBITDAR are significantly smaller, less profitable and higher levered. They also have more tangible and intangible assets, providing strong evidence for Hypotheses 1, 2, 3a and 3b. The magnitude of the coefficients is generally larger than in Table 4, in line with the idea that adjusted EBITDA measures are more opportunistic in nature than EBITDA disclosures. Interestingly, when only considering EBITDA reporting firms (specification (4)), we still find that firms disclosing Adjusted EBITDA or EBITDAR are smaller, less profitable and more capital intensive. When testing equivalent specifications (5) and (6) for adjusted EBITDA disclosures in earnings announcements we find very similar results, with highly significant coefficients for Firm Size, ROA and Leverage in the predicted directions. Finally, we note that Sales Growth is positively associated with the disclosure of adjusted EBITDA numbers. This finding is in line with what Brown, Christensen, Menini and Steffen (2017) report in a recent paper as they find that IPO firms frequently disclose adjusted EBITDA.

\footnotetext{
${ }^{16}$ We omit the variables Change in WC, Forecast Miss and Forecast Error to keep more observations. When including them, the results remain the same and coefficients on these variables are generally not significant.
} 


\subsection{EBITA and EBIT disclosures}

In a next set of analyses, we consider determinants of the likelihood of EBITA and EBIT disclosures. EBIT equals EBITDA minus depreciation and amortization and usually refers to the notion of operating income (before tax). EBITA equals EBITDA minus depreciation and lies in between EBIT and EBITDA. ${ }^{17}$ As a performance metric, EBITA and especially EBIT have less of an opportunistic nature than EBITDA. Put differently, if management is looking for a measure to window-dress performance or deviate attention from a bad bottom-line earnings number, it will be much less served by an EBITA or EBIT number. Moreover, the concept of EBIT or operating income is much more accepted as a measure of operating performance. Therefore, we expect to find weaker results than we did so far and we do not expect our hypotheses to longer hold. Results are summarized in Table 8.

In Panel A we show results for EBITA and EBIT disclosures in annual reports, including all our test variables and in Panel B we test for these disclosures in earnings announcements. ${ }^{18}$ In both panels, it is immediately clear that the firm characteristics are not as good in explaining the disclosure of EBITA and EBIT as they are in explaining EBITDA disclosures. We derive this conclusion from both the low amount of significant explanatory variables in the model and the much lower R-squared. This result is in line with our predictions.

One particular result we would like to highlight is the coefficient on Intangibles. When testing for the disclosure of EBITA (specifications (1) and (2)), we find a significantly positive coefficient on Intangibles, as we did when testing for the disclosure of EBITDA in Table 4. This finding is in line with the prediction that firms with more intangible assets typically have higher amortization amounts and will therefore be better served when showing a measure excluding this expense item. EBITDA and EBITA indeed exclude amortization expense. However, EBIT does not exclude this item and in specifications (3) and (4) we indeed

\footnotetext{
${ }^{17}$ EBITA is mentioned at least once in the annual report of $0.4 \%$ of firms and EBIT in about $10 \%$ of the annual reports. ${ }^{18}$ Unlike previous analyses, we do not include industry fixed effects in this set of analyses as we lose too many observations (i.e. there are too many SIC 2-digit industries in which there is no firm that discloses EBITA or EBIT).
} 
no longer find a significant coefficient on Intangibles. Equally worth mentioning is that the coefficient on Capital Intensity, an indicator of depreciation expense, is not significant in explaining either EBITA or EBIT, while we did find a positive coefficient on Capital Intensity when testing for EBITDA disclosures.

\subsection{Complementarities among EBITDA-related disclosures}

In a final set of analyses, we investigate any complementary effects in disclosure of EBITDA, adjusted EBITDA, EBITDAR, EBITA and EBIT. For instance, to what extent is the likelihood of a firm disclosing adjusted EBITDA related to whether EBITDA is also disclosed? Results are summarized in Table 9. In Panel A, we show the proportion of firms disclosing (1) EBITDA; (2) EBITDAR or adjusted EBITDA (jointly labelled Adjusted EBITDA) and (3) EBITA or EBIT (as one category), relative to each other. ${ }^{19}$ Results convey that, of all firms not disclosing EBITDA, only 10.85\% disclose an adjusted EBITDA figure. This proportion is significantly lower than for EBITDA disclosers where $46 \%$ of firms also report adjusted EBITDA. This result suggests that EBITDA and adjusted EBITDA act primarily as complements to each other. Further in the table, the difference between the $7.5 \%$ vs $36.09 \%$ further underscores this finding. Regarding EBIT or EBITA versus EBITDA, we do not notice any large differences in disclosure proportions. The small differences show that firms disclosing EBITDA are slightly less likely to disclose EBIT or EBITA and vice versa, which would hint at these acting as substitutes rather than complements. However, the differences are small. Finally, we find that firms not disclosing any adjusted EBITDA figure, have a probability of $8.46 \%$ to disclose EBIT or EBITA, while this probability is only $3.54 \%$ for firms that do provide an adjusted EBITDA figure suggesting that these two sets of metrics do not tend to be disclosed together.

Following up on the previous test, we redo our main tests and include an indicator on the disclosure of an alternative measure. Untabulated results show that the presence of adjusted EBITDA positively relates to

\footnotetext{
${ }^{19}$ We consider EBIT and EBITA as one category because the two are closely linked to each other and because of the relatively small of EBITA disclosures.
} 
the likelihood of EBITDA disclosure, both in annual reports and in earnings announcement reports. We fail to find any significant association between EBIT (or EBITA) disclosure and EBITDA disclosure likelihood, and neither between EBIT (or EBITA) and adjusted EBITDA.

In our sample we find that $26.3 \%$ of the firms provide at least one of the five non-GAAP measures considered in this study and $6.3 \%$ provide two or more of these measures in the annual report. To further investigate why some firms choose to disclose only one measure while others provide multiple measures, we run an ordered logit model with the sum of indicator variables for the disclosure of Adjusted EBITDA, EBITDAR, EBITDA, EBITA and EBIT as the dependent variable, ranging from 0 to 5. Results are shown in Panel B of Table 9. In specifications (1) and (2), for disclosures in annual reports, and in specification (4), for earnings announcements, we find coefficients of similar significance and interpretation as those reported in the main tables. Small firms, capital-intensive firms, highly leveraged firms and firms with more working capital needs disclose a higher amount of non-GAAP metrics. Specifications (3) and (5) provide a stronger test as observations without non-GAAP disclosures are dropped. All firms in these tests disclose at least one of the five considered measures. ${ }^{20}$ Interestingly, we find strong evidence for the notion that firms disclosing multiple non-GAAP measures are significantly smaller and more leveraged than firms only disclosing one of such measures.

In a final test on interdependencies between non-GAAP measures, we shed light on whether and how EBITDA disclosure depends on the sign of EBIT and EBITDA. To do so, we split the sample in three groups: firms with both negative EBIT and negative EBITDA (group 1), those with negative EBIT but positive EBITDA (group 2), and those for which both EBIT and EBITDA is positive (group 3). Given a negative EBIT, we predict a higher likelihood of EBITDA disclosure when EBITDA is positive, compared to when EBITDA is negative (i.e. testing the difference between group 1 and group 2). Our prediction when

\footnotetext{
${ }^{20}$ In specification (3) we exclude the analyst forecast variables in order to prevent the number of observations dropping further.
} 
comparing group 2 with group 3 is that, given a positive EBITDA, firms are more likely to disclose EBITDA when EBIT is negative, compared to when EBIT is positive.

Results are shown in Panel C of Table 9. In specifications (1) and (3), we include EBITDA Loss, an indicator variable equal to 1 if EBITDA is negative, zero otherwise. We deliberately test a short model and leave out control variables which would otherwise even further decrease the sample size. In specifications (2) and (4), we include EBIT Loss, an indicator variable equal to 1 if EBIT is negative and zero otherwise. We also exclude ROA, to avoid multicollinearity. In line with expectations, we find a significantly negative coefficient on EBITDA Loss in specification (1). This result suggests that firms with negative EBIT but positive EBITDA are more likely to disclose EBITDA in their annual report than firms with both negative EBIT and negative EBITDA. Although weaker, we find a similar result in specification (3), testing for EBITDA disclosures in earnings announcements. In specifications (2) and (4), we do not find that firms with a negative EBIT are more likely to disclose EBITDA. However, the coefficient on EBIT Loss is positive in both cases and close to being significant with p-values of 0.13 in specification (2) and 0.16 in specification (4).

\section{Conclusion}

EBITDA is a popular financial metric often disclosed to report on company performance. EBITDA serves as a hybrid financial concept that combines elements of both earnings and cash flows. However, EBITDA conveys both cash flow and accrual information in an imperfect manner, leaving the financial statement user with the question what incremental information EBITDA actually conveys about the performance of a company. By design of EBITDA, the number is (almost) always higher than any conventional earnings or cash flow number. American as well as international oversight bodies have raised concerns to such an extent that the IASB does not want to define EBITDA and the SEC may start regulating it. We conjecture that EBITDA numbers distract the attention from economic events relevant to investors. 
We find that 25 percent of firms report EBITDA numbers in their annual report, while 18 percent of the press releases refer to EBITDA. Their use is persistent over time and seems to have slightly increased since 2005. The criticism voiced over EBITDA has not eased over time. While we establish that EBITDA has little or no incremental informational value and the concept is exposed to criticism, we ask the question why its use is so widespread all the same. To that end we examine the prediction that EBITDA lends itself as a convenient tool to improve the outlook of firm performance and a measure that helps to conceal low profitability levels, high leverage levels and overinvestment.

Our empirical analyses show that EBITDA-reporting firms are smaller than firms that never talk about EBITDA, and have larger analyst forecast errors. This finding is consistent with the notion that potential reputation loss of providing low quality financial information is lower for smaller firms than for more reputed firms. EBITDA-reporting firms also carry more debt on their balance sheet, have a higher probability of missing the earnings benchmark set by analysts, and invest more in tangible and intangible long-term assets. One particular result, and never documented in the literature, is that firms with higher and increasing requirements for working capital are more likely to disclose EBITDA. Until now, the literature has mostly focused on items left out of non-GAAP earnings compared to earnings, not compared to cash flows. Therefore, this latter result carries an important implication for the non-GAAP literature, in that, it suggests managers do not merely seek to make earnings look better, but also (operating) cash flow. Another contribution to the literature is that we investigate determinants of adjusted EBITDA disclosures, including EBITDAR. We find strong evidence consistent with the idea that these disclosures are used in an opportunistic fashion to over-present performance. We find only weak evidence that EBITA and EBIT are disclosed for opportunistic reasons. In sum, we contribute to the literature by providing evidence that EBITDA, and its adjusted measures, are well-suited financial metrics to window-dress performance and provide a rosier picture of the company than what is shown by conventional earnings and cash flow measures. 
We acknowledge that in our paper we primarily ask the question why firms choose to show EBITDA numbers. We do not claim that the use of EBITDA has negative effects for investors or that EBITDA disclosures should always be interpreted as opportunistic. Rather, our findings imply users of financial information to be cautious when management emphasizes EBITDA. EBITDA measures are used intensively in practice and we could only provide some answers of why that is. In debt covenants, EBITDA plays almost without exception a prime role. We leave it to future work to enhance our understanding of why lenders would benefit if they contract on EBITDA numbers instead of regulated numbers. Another potentially fruitful avenue for future research is to investigate substitution and complementary effects of different non-GAAP disclosure items. Our additional tests provide some indications of such interdependencies. For instance, we notice that EBITDA disclosures are usually complementary to adjusted EBITDA disclosures, while they are not so to EBIT disclosures. Also, firms with an EBIT loss are more likely to disclose EBITDA when EBITDA is positive compared to firms with a negative EBITDA. Further investigation is required to provide more insights on complementarities between different non-GAAP disclosure metrics. Our study only considers a subset of non-GAAP disclosures and our analyses can be considered as a first step towards that research objective. 


\section{References}

Ball, R. 1989. The firm as a specialist contracting intermediary: application to accounting and auditing. Working paper, William E. Simon Graduate School of Business Administration, University of Rochester.

Ball, R., S. Jayaraman and L. Shivakumar. 2012. Audited financial reporting and voluntary disclosure as complements: A test of the confirmation hypothesis, Journal of Accounting and Economics, 53 (1\&2): 136166

Barth, M.E., Gow, I.D. and Taylor, D.J. 2012. Why do pro forma and Street earnings not reflect changes in GAAP? Evidence from SFAS 123R Review of Accounting Studies: 17 (3): 526-562.

Beaver, W. and S. Ryan. 2000. Biases and lags in book value and their effects on the ability of the bookto-market ratio to predict book return on equity. Journal of Accounting Research 38: 127-148.

Bhattacharya, N., E. Black, T. E. Christensen, and C. Larson. 2003. Assessing the Relative Informativeness and Permanence of Pro Forma Earnings and GAAP Operating Earnings, Journal of Accounting and Economics, Vol. 36, No. 1, pp. 285-319.

Bhattacharya, N., E. Black, T. E. Christensen and D. Mergenthaler. 2004. Empirical evidence on recent trends in pro forma reporting. Accounting Horizons 18(1): 27-43.

Black, D. E. and T. E. Christensen. 2009. US managers' use of 'pro forma' adjustments to meet strategic earnings targets. Journal of Business Finance and Accounting 36(3\&4): 297-326.

Black, D. E., T. E. Christensen, J. T. Ciesielski, AND B. C. Whipple. 2018. Non-GAAP Earnings: A Consistency and Comparability Crisis?'. Working paper, https://papers.ssrn.com/sol3/papers.cfm?abstract_id=2759312 (2017a).

Botosan, C. and M. Plumlee. 2002. A Re-examination of Disclosure Level and the Expected Cost of Equity Capital, Journal of Accounting Research, 40, pp. 21-40.

Botosan, C. and M. Stanford. 2005. Managers' Motives to Withhold Segment Disclosures and the Effect of SFAS No. 131 on Analysts' Information Environment. The Accounting Review, 80, 751-772.

Bowen, R., A. Davis, and D. Matsumoto. 2005. Emphasis on Pro Forma versus GAAP Earnings in Quarterly Press Releases: Determinants, SEC Intervention, and Market Reactions, The Accounting Review 80(4): 1011-1038

Brown, N., T. Christensen, A. Menini, and T. Steffen. 2017. 'Non-GAAP Earnings Disclosures and IPO Pricing, Working paper.

Buffet, W. 2001. 2000 Annual Report, Berkshire Hathaway, page 17 http://www.berkshirehathaway.com/2000ar/2000ar.pdf

Buffet, W. 2002. 2001 Annual Report, Berkshire Hathaway, page 14, http://www.berkshirehathaway.com/2001ar/2001ar.pdf

Buffett, W. 2002. In the Chairman's letter of the 2001 annual report of Berkshire Hathaway, http://www.berkshirehathaway.com/2001ar/impnote01.html 
Bushman, R. M., Piotroski, J. D. and Smith, A. J. 2004. What determines corporate transparency?. Journal of Accounting Research, 42(2): 207-252.

Chava, S. and M. Roberts. 2008. How does financing impact investment? The role of debt covenants. Journal of Finance 63: 2085-2121.

Christensen, H., E. Lee, and M. Walker. 2009. Do IFRS Reconciliations Convey Information? The Effect of Debt Contracting, Journal of Accounting Research 47(5): 1167-1199.

D'souza, J. D., K. Ramesh, and M. Shen. 2010. Disclosure of GAAP line items in earnings announcements. Review of Accounting Studies 15(1): 179-219.

Deloitte. 2016. A Roadmap to Non-GAAP Financial Measures.

Demerjian, P. and E. Owens. 2016. Measuring the probability of financial covenant violation in private debt contracts, Journal of Accounting and Economics, 61, 433-447

Depoers, F. 2000. A cost-benefit study of voluntary disclosure: some empirical evidence from French listed companies. European Accounting Review, 9(2): 245-263.

Doyle, J., R. Lundholm, M. Soliman. 2003. The Predictive Value of Expenses Excluded from Pro Forma Earnings, Review of Accounting Studies, 8, 145-174.

Easton, P., M. Lea McAnally, G. Sommers, and X. Zhang. 2015. Financial Statement Analysis \& Valuation, $4^{\text {th }}$ editions Cambridge Business Publishers.

Financial Times. 11 May 2016. 'Misleading' numbers used to boost management pay: https://www.ft.com/content/2a54da40-1771-11e6-9d98-00386a18e39d .

Forbes, March 17 2003. "The Ebitda Folly".

Garcia-Meca, E. and J.P Sanchez-Ballesta. 2010. The association of board independence and owernship concentration with voluntary disclosure: A Meta-Analysis. European Accounting Review, 19, 603-627

Guillamon-Saorin, E., H. Isidro, and A. Marques (2017), 'Impression Management and Non-GAAP Disclosure in Earnings Announcements', Journal of Business Finance \& Accounting, Vol. 44, Issues 3-4, pp. 448-479.

Hanlon, M., and S. Heitzman. 2010. A review of tax research. Journal of Accounting and Economics 50(23): $127-178$.

Hoogervorst, H. 2016. http://www.ifrs.org/About-us/IASB/Members/Documents/Hans-HoogervorstEAA-Annual-Conference-11-May-2016.pdf.

Isidro, H. and A. Marques (2015), 'The Role of Institutional and Economics Factors in the Strategic Use of Non-GAAP Disclosures to Beat Earnings Benchmarks', European Accounting Review, Vol. 24, No. 1, pp. 95-128.

Israeli, D. 2015. Recognition versus disclosure: evidence from fair value of investment property. Review of Accounting Studies: 20(4): 1457-1503. 
Kang, S., and Y. Zhao. 2010. Information Content and Value Relevance of Depreciation: A Cross-Industry Analysis. The Accounting Review, 85(1), 227-260.

Kolev, K., C. A. Marquadt, and S. E. McVay. 2008. SEC Scrutiny and the Evolution of Non-GAAP Reporting. The Accounting Review 83: 157-184.

Lahart, J. (February 24, 2016). S\&P 500 Earnings: Far Worse Than Advertised. The Wall Street Journal.

Laux, R.C. 2013. The Association between Deferred Tax Assets and Liabilities and Future Tax Payments. The Accounting Review 88(4): 1357-1383.

Leung, E. and D. Veenman. 2018. Non-GAAP Earnings Disclosure in Loss Firms. Journal of Accounting Research, forthcoming.

Li, N. 2016. Performance measures in earnings-based financial covenants in debt contracts. Journal of Accounting Research 54(4): 1149-1186.

Liu, J., D. Nissim, and J. Thomas. 2002. Equity Valuation Using Multiples. Journal of Accounting Research, 40(1): 135-172.

Liu, J., D. Nissim, and J. Thomas. 2007. Is Cash Flow King in Valuations? Financial Analysts Journal 63(2): 56-65.

Lougee, B. A., and C. A. Marquadt. 2004. Earnings Informativeness and Strategic Disclosure: An Empirical Examination of "Pro Forma" Earnings. The Accounting Review 79: 769-795.

Nissim, D., and S. Penman. 2001. Ratio analysis and equity valuation: From research to practice. Review of Accounting Studies (March): 109-154.

Nissim, D. 2017. EBITDA, EBITA, or EBIT? Columbia Business School Research Paper No. 17-71. Available at SSRN: $\underline{\text { https://ssrn.com/abstract }=2999675}$

Opler, T., L. Pinkowitz, R. Stulz, and R. Williamson. 1999. The determinants and implications of corporate cash holdings. Journal of Financial Economics 52(1): 3-46.

Penman, S. 2013. Financial Statement Analysis and Security Valuation, $5^{\text {th }}$ edition, McGraw-Hill Higher Education.

Prencipe, A. 2004. Proprietary costs as determinants of voluntary segment disclosure: evidence from Italian listed companies. European Accounting Review, 13(2): 319-340.

Raffournier, B. 1995. The determinants of voluntary financial disclosure by Swiss listed companies, European Accounting Review, 4, 261-280.

Rozenbaum, O. 2018. EBITDA and Managers' Investment and Leverage Choices. Contemporary Accounting Research, forthcoming.

SEC. 2002. Release No. 33-8176; 34-47226; FR-65; FILE NO. S7-43-02. https://www.sec.gov/rules/final/33-8176.htm

SEC. 2010. FAQS: https://www.sec.gov/divisions/corpfin/faqs/nongaapfaq.htm. 
Sengupta, P. 1998. Corporate Disclosure Quality and the Cost of Debt, The Accounting Review 73(4): 459474.

Sherman, H.D. and S.D. Young. 2016. Why financial reporting still falls short. Harvard Business Review, July-August 4.

Smith, M. and B. Stradley. 2010. New research tracks the evolution of annual incentives plans. Towers Watson Executive compensation bulletin, February 25, 2010.

Verriest, A., A. Gaeremynck and D. Thornton. 2013. The impact of corporate governance on IFRS adoption choices. European Accounting Review, 22(1), 39-77.

WSJ 4 August 2016: http://www.wsj.com/articles/companies-routinely-steer-analysts-to-deliver-earningssurprises-1470326310.

WSJ 16 March 2016: http://www.wsj.com/articles/sec-scrutinizing-use-of-non-gaap-measures-by-publiccompanies-1458139473.

WSJ 13 July 2016: http://blogs.wsj.com/cfo/2016/07/13/cfos-may-get-more-accounting-guidance-from$\underline{\mathrm{iasb} /}$ 
Appendix: List of Variables

\begin{tabular}{|c|c|}
\hline Variable & Definition \\
\hline Capex & Capital expenditure scaled by total assets \\
\hline Capital Intensity & The amount of property, plant and equipment (net) scaled by total assets \\
\hline Cash & The amount of cash and cash equivalents scaled by total assets \\
\hline Change in WC & $\begin{array}{l}\text { Change in working capital measured by the yearly change in current } \\
\text { operating assets (current assets minus cash and cash equivalents) minus the } \\
\text { yearly change in current operating liabilities (current liabilities minus short- } \\
\text { term debt and other nonoperating current liabilities), scaled by total assets. A } \\
\text { positive change indicates an increase in the need for working capital. }\end{array}$ \\
\hline Cycle & $\begin{array}{l}\text { Operating cycle of a firm's operations measured as inventories plus accounts } \\
\text { receivable minus accounts payable, scaled by total assets. }\end{array}$ \\
\hline Drop in earnings & $\begin{array}{l}\text { Indicator variable equal to } 1 \text { if the firm has registered a drop in earnings } \\
\text { compared to the previous period, zero otherwise. }\end{array}$ \\
\hline EBITDA & $\begin{array}{l}\text { Indicator variable equal to } 1 \text { if the firm has mentioned "EBITDA" three times } \\
\text { or more in the current year annual report (10-k from EDGAR) or in the press } \\
\text { releases of earnings announcement of quarterly or annual earnings numbers } \\
\text { (available in EDGAR), zero otherwise. }\end{array}$ \\
\hline $\begin{array}{l}\text { EBITDA in Prior } \\
\text { Year }\end{array}$ & $\begin{array}{l}\text { Indicator variable equal to } 1 \text { if the firm has mentioned "EBITDA" three times } \\
\text { or more in the previous year annual report (10-k from EDGAR) or the } \\
\text { previous earnings announcement, zero otherwise. }\end{array}$ \\
\hline EBITDA Count & $\begin{array}{l}\text { The natural log of one plus the number of times "EBITDA" is mentioned in } \\
\text { the annual report or earnings announcement report. }\end{array}$ \\
\hline EBITDA Loss & $\begin{array}{l}\text { Indicator variable equal to } 1 \text { if the firm has a negative EBITDA in the current } \\
\text { fiscal period, and zero otherwise. }\end{array}$ \\
\hline EBIT Loss & $\begin{array}{l}\text { Indicator variable equal to } 1 \text { if the firm has a negative EBIT in the current } \\
\text { fiscal period, and zero otherwise. }\end{array}$ \\
\hline Firm Size & $\begin{array}{l}\text { Market capitalization measured as the stock price per share at the end of the } \\
\text { fiscal period multiplied by the number of shares outstanding. }\end{array}$ \\
\hline Forecast Error & $\begin{array}{l}\text { The absolute difference between actual EPS and forecasted EPS, scaled by } \\
\text { lagged price per share. Earnings forecasts and actual earnings are retrieved } \\
\text { from IBES. We use the average last consensus forecast of one-year ahead } \\
\text { EPS available. }\end{array}$ \\
\hline
\end{tabular}




\begin{tabular}{|c|c|}
\hline Forecast Miss & $\begin{array}{l}\text { Indicator variable equal to } 1 \text { if actual EPS is lower than the average last } \\
\text { consensus forecast of EPS, and zero otherwise. Earnings forecasts and actual } \\
\text { earnings are retrieved from IBES. }\end{array}$ \\
\hline Free Cash Flow & $\begin{array}{l}\text { Net operating profit minus changes in net operating assets. Free cash flow is } \\
\text { defined as in Penman (2013). }\end{array}$ \\
\hline Intangibles & The amount of intangible assets (excluding goodwill) scaled by total assets. \\
\hline Interest Exp & $\begin{array}{l}\text { The interest expense as mentioned in the income statement scaled by } \\
\text { revenues. }\end{array}$ \\
\hline Leverage & $\begin{array}{l}\text { The total amount of debt a firm has on its balance sheet (long-term and short- } \\
\text { term) scaled by total assets. }\end{array}$ \\
\hline Loss firm & $\begin{array}{l}\text { Indicator variable equal to } 1 \text { if the firm has registered a loss (net income }<0 \text { ), } \\
\text { zero otherwise. }\end{array}$ \\
\hline Market to Book & $\begin{array}{l}\text { Market-to-book ratio measured as market capitalization scaled by book value } \\
\text { of equity. }\end{array}$ \\
\hline Net Operating Profit & $\begin{array}{l}\text { Operating profit after tax, defined as in Penman (2013), measured as } \\
\text { operating profit minus tax shield. Tax shield is actual tax expense plus the } \\
\text { statutory tax rate multiplied by nonoperating expenses (e.g. interest } \\
\text { expenses). Sometimes referred to as NOPAT, or net operating profit after tax. }\end{array}$ \\
\hline NOA & $\begin{array}{l}\text { Net operating assets defined as operating assets minus operating liabilities. } \\
\text { Operating assets include accounts receivable and inventories and exclude } \\
\text { cash and equivalents. Operating liabilities include accounts payable, wages } \\
\text { payable, pension liabilities and exclude debt. We refer to Easton, McAnally, } \\
\text { Sommers and Zhang (2015) for a detailed discussion. }\end{array}$ \\
\hline Operating Cash Flow & $\begin{array}{l}\text { Operating cash flow number as it appears on the cash flow statement } \\
\text { (sometimes referred to as (net) cash flow from operations) and measured as } \\
\text { the cash inflow that stems from operating activities of the firm. }\end{array}$ \\
\hline Operating Profit & $\begin{array}{l}\text { Sales minus operating expenses including cost of sales, S,G\&A and R\&D, } \\
\text { before tax. }\end{array}$ \\
\hline ROA & $\begin{array}{l}\text { Return on assets measured as net income (before extraordinary items) scaled } \\
\text { by total assets. }\end{array}$ \\
\hline ROE & $\begin{array}{l}\text { Return on equity measured as net income (before extraordinary items) scaled } \\
\text { by book value of equity. }\end{array}$ \\
\hline ROS & $\begin{array}{l}\text { Return on equity measured as net income (before extraordinary items) scaled } \\
\text { by total revenues. }\end{array}$ \\
\hline $\mathbf{R} \& \mathbf{D}$ & Research and development expense scaled by total revenues. \\
\hline
\end{tabular}




\begin{tabular}{|l|l|}
\hline Sales growth & The percentage change in annual revenues. \\
\hline Tax Rate & $\begin{array}{l}\text { The effective tax rate of a firm measured as the tax expense scaled by pre-tax } \\
\text { income. }\end{array}$ \\
\hline
\end{tabular}


Figure 1: EBITDA Reporting over time

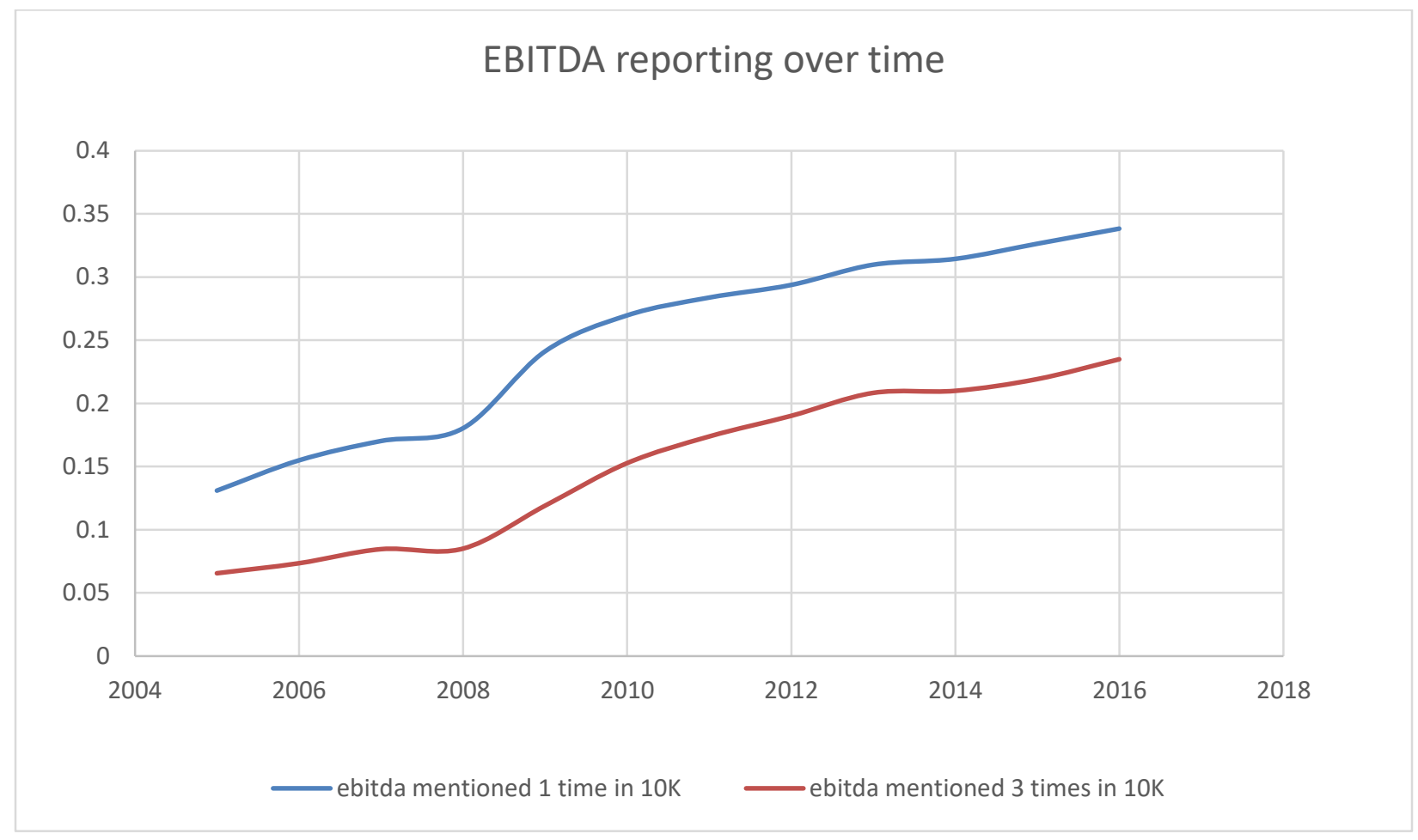

This figure shows how reporting of EBITDA in 10-K's has evolved over time for the period 2005-2016 for stocklisted firms belonging to the S\&P 1500 index. The blue line shows the percentages of annual reports that contains at least 1 EBITDA mention and the red line denotes the percentage of firms that mention EBITDA at least 3 times. 
Table 1: Comparison of EBITDA with Other Earnings and Cash Flow Measures

Panel A: Median Values of Cash Flow, Earnings and EBITDA Ratios

\begin{tabular}{|c|c|c|c|c|c|}
\hline Type & Metric & Definition & Total Sample & S\&P 500 & DOW 30 \\
\hline \multicolumn{6}{|l|}{ Net Income } \\
\hline 1. & ROS & Return on Sales & $1.64 \%$ & $7.11 \%$ & $9.70 \%$ \\
\hline 2. & ROA & Return on Assets & $1.53 \%$ & $5.93 \%$ & $8.13 \%$ \\
\hline & ROE & Return on Equity & $7.87 \%$ & $14.72 \%$ & $20.04 \%$ \\
\hline \multicolumn{6}{|c|}{ Net Operating Profit } \\
\hline 4. & NOPM & Net Operating Profit Margin (NOPM) & $2.99 \%$ & $8.62 \%$ & $11.62 \%$ \\
\hline & RNOA & Return on Net Operating Assets (NOA) & $7.09 \%$ & $12.55 \%$ & $16.91 \%$ \\
\hline \multicolumn{6}{|c|}{ Operating Profit (Before tax) } \\
\hline 6 & OPER_PROF/SALES & Operating Profit Margin & $4.66 \%$ & $13.16 \%$ & $17.15 \%$ \\
\hline & OPER_PROF/TA & Operating Profit on Assets & $4.84 \%$ & $10.52 \%$ & $12.51 \%$ \\
\hline 8. & OPER_PROF/NOA & Operating Profit on NOA & $10.67 \%$ & $19.08 \%$ & $25.03 \%$ \\
\hline \multicolumn{6}{|c|}{ Free Cash Flow } \\
\hline & FCF/SALES & Free Cash Flow Margin & $-0.39 \%$ & $4.96 \%$ & $7.91 \%$ \\
\hline & FCF/TA & Free Cash Flow on Assets & $-0.98 \%$ & $4.82 \%$ & $6.54 \%$ \\
\hline 11. & FCF/NOA & Free Cash Flow on NOA & $0.96 \%$ & $8.19 \%$ & $12.63 \%$ \\
\hline \multicolumn{6}{|c|}{ Operating Cash Flow } \\
\hline 12 . & OPER_CF/SALES & Operating Cash Flow Margin & $5.07 \%$ & $13.08 \%$ & $17.27 \%$ \\
\hline & OPER_CF/TA & Operating Cash Flow on Assets & $5.19 \%$ & $10.92 \%$ & $13.36 \%$ \\
\hline 14. & OPER_CF/NOA & Operating Cash Flow on NOA & $10.70 \%$ & $19.20 \%$ & $25.18 \%$ \\
\hline \multicolumn{6}{|l|}{$E B I T D A$} \\
\hline 15 . & EBITDA/SALES & EBITDA Margin & $8.79 \%$ & $18.91 \%$ & $23.34 \%$ \\
\hline 16. & EBITDA/TA & EBITDA on Assets & $9.35 \%$ & $15.28 \%$ & $17.15 \%$ \\
\hline 17. & EBITDA/NOA & EBITDA on NOA & $18.00 \%$ & $27.32 \%$ & $34.50 \%$ \\
\hline
\end{tabular}


Table 1 (Cont.)

Panel B: EBITDA Figures per Quarter of ROE, NOPM and Operating Cash Flow (for S\&P 500)

\begin{tabular}{|c|c|c|c|c|}
\hline \multirow[t]{2}{*}{ Metric split in quarters: } & \multicolumn{4}{|c|}{ ROE } \\
\hline & Q1 & Q2 & Q3 & Q4 \\
\hline Median ROE per quartile: & $-40.13 \%$ & $3.42 \%$ & $13.30 \%$ & $25.09 \%$ \\
\hline \multicolumn{5}{|l|}{ Median EBITDA Metric per quartile } \\
\hline EBITDA/SALES & $7.67 \%$ & $15.19 \%$ & $19.58 \%$ & $20.55 \%$ \\
\hline EBITDA/TA & $7.08 \%$ & $9.56 \%$ & $14.35 \%$ & $20.97 \%$ \\
\hline \multirow[t]{3}{*}{ EBITDA/NOA } & $11.73 \%$ & $16.63 \%$ & $24.60 \%$ & $40.96 \%$ \\
\hline & \multicolumn{4}{|c|}{ Net Operating Profit Margin } \\
\hline & Q1 & Q2 & Q3 & Q4 \\
\hline Median NOPM per quartile: & $-28.55 \%$ & $1.63 \%$ & $5.57 \%$ & $13.02 \%$ \\
\hline \multicolumn{5}{|l|}{ Median EBITDA Metric per quartile } \\
\hline EBITDA/SALES & $-9.14 \%$ & $5.60 \%$ & $12.66 \%$ & $26.28 \%$ \\
\hline EBITDA/TA & $-4.89 \%$ & $9.82 \%$ & $15.26 \%$ & $17.08 \%$ \\
\hline \multirow[t]{3}{*}{ EBITDA/NOA } & $-8.52 \%$ & $20.00 \%$ & $26.98 \%$ & $30.84 \%$ \\
\hline & \multicolumn{4}{|c|}{ Operating Cash Flow on Assets } \\
\hline & Q1 & Q2 & Q3 & Q4 \\
\hline Median Operating CF per quartile: & $-11.58 \%$ & $3.32 \%$ & $8.38 \%$ & $15.59 \%$ \\
\hline \multicolumn{5}{|l|}{ Median EBITDA Metric per quartile } \\
\hline EBITDA/SALES & $-3.97 \%$ & $13.13 \%$ & $18.02 \%$ & $21.57 \%$ \\
\hline EBITDA/TA & $-6.02 \%$ & $8.30 \%$ & $12.57 \%$ & $20.16 \%$ \\
\hline EBITDA/NOA & $-6.63 \%$ & $14.97 \%$ & $21.66 \%$ & $37.52 \%$ \\
\hline
\end{tabular}

Panel C: EBITDA versus others: Which is Higher?

\begin{tabular}{rlccc}
\hline \multicolumn{1}{c}{ Type } & \multicolumn{1}{c}{ Metric } & $\begin{array}{c}\text { Total } \\
\text { Sample }\end{array}$ & S\&P 500 & DOW 30 \\
\hline Percentage of firms for which: & & & \\
1. & EBITDA $>$ Net Operating Profit & $93 \%$ & $99 \%$ & $99 \%$ \\
2. & EBITDA $>$ Gross Profit & $13 \%$ & $14 \%$ & $3 \%$ \\
3. & EBITDA $>$ Free Cash Flow & $70 \%$ & $87 \%$ & $89 \%$ \\
4. & EBITDA $>$ Operating Cash Flow & $66 \%$ & $85 \%$ & $90 \%$ \\
\hline
\end{tabular}

Table 1 shows how EBITDA numbers and EBITDA-based ratios compare with earnings and cash flow based numbers and ratios. The sample used in this table includes data from all stock-listed US firms available in Compustat between 1988 and 2016. Financial firms are excluded. Panel A shows median values of cash flow, earnings and EBITDA ratios, for the total sample and the S\&P 500 and DOW 30 subsamples. Panel B shows, for the S\&P 500 sample, medians of EBITDA for each quartile of return on equity (ROE), net operating profit margin (NOPM) and operating cash flow scaled by total assets. Panel C shows the proportion of firms for which EBITDA is larger than earnings and cash flows, for the total sample and the S\&P 500 and DOW 30 subsamples. 
Table 2: Descriptive Statistics

Panel A: EBITDA Reporting by Fama-French Industry

\begin{tabular}{|c|c|c|}
\hline Industry & Industry Name & $\%$ of firms reporting EBITDA \\
\hline 2 & Food Products & $12.9 \%$ \\
\hline 4 & Beer \& Liquor & $5.2 \%$ \\
\hline 5 & Tobacco Products & $11.4 \%$ \\
\hline 6 & Recreation & $16.9 \%$ \\
\hline 7 & Entertainment & $36.1 \%$ \\
\hline 8 & Printing and Publishing & $19.6 \%$ \\
\hline 9 & Consumer Goods & $11.3 \%$ \\
\hline 10 & Apparel & $6.9 \%$ \\
\hline 11 & Healthcare & $20.0 \%$ \\
\hline 12 & Medical Equipment & $10.5 \%$ \\
\hline 13 & Pharmaceutical Products & $5.0 \%$ \\
\hline 14 & Chemicals & $14.0 \%$ \\
\hline 15 & Rubber and Plastic Products & $15.2 \%$ \\
\hline 16 & Textiles & $38.3 \%$ \\
\hline 17 & Construction Materials & $28.7 \%$ \\
\hline 18 & Construction & $21.2 \%$ \\
\hline 19 & Steel Works Etc & $19.8 \%$ \\
\hline 20 & Fabricated Products & $18.2 \%$ \\
\hline 21 & Machinery & $15.2 \%$ \\
\hline 22 & Electrical Equipment & $18.4 \%$ \\
\hline 23 & Automobiles and Trucks & $16.7 \%$ \\
\hline 24 & Aircraft & $26.8 \%$ \\
\hline 25 & Shipbuilding, Railroad Equipment & $17.1 \%$ \\
\hline 26 & Defense & $17.3 \%$ \\
\hline 27 & Precious Metals & $16.7 \%$ \\
\hline 28 & Non-Metallic and Industrial Metal Mining & $32.9 \%$ \\
\hline 29 & Coal & $36.4 \%$ \\
\hline 30 & Petroleum and Natural Gas & $12.4 \%$ \\
\hline 31 & Utilities & $5.3 \%$ \\
\hline 32 & Communication & $25.7 \%$ \\
\hline 33 & Personal Services & $22.1 \%$ \\
\hline 34 & Business Services & $17.1 \%$ \\
\hline 35 & Computer Hardware & $4.1 \%$ \\
\hline 36 & Computer Software & $6.9 \%$ \\
\hline 37 & Electronic Equipment & $2.9 \%$ \\
\hline 38 & Measuring and Control Equipment & $12.0 \%$ \\
\hline 39 & Business Supplies & $24.4 \%$ \\
\hline 40 & Shipping Containers & $5.1 \%$ \\
\hline 41 & Transportation & $13.9 \%$ \\
\hline 42 & Wholesale & $13.3 \%$ \\
\hline 43 & Retail & $13.8 \%$ \\
\hline 44 & Restaurants, Hotels, Motels & $1.5 \%$ \\
\hline 45 & Banking & $4.2 \%$ \\
\hline 46 & Insurance & $63.7 \%$ \\
\hline 47 & Real Estate & $13.9 \%$ \\
\hline 48 & Trading & $27.7 \%$ \\
\hline
\end{tabular}


Table 2 (cont.)

Panel B: Number of firms starting/stopping the disclosure of EBITDA

\begin{tabular}{ccc} 
year & stop & begin \\
\hline 2006 & 19 & 25 \\
2007 & 17 & 32 \\
2008 & 25 & 28 \\
2009 & 13 & 65 \\
2010 & 22 & 66 \\
2011 & 21 & 50 \\
2012 & 27 & 64 \\
2013 & 22 & 52 \\
2014 & 40 & 41 \\
2015 & 39 & 61 \\
2016 & 40 & 41 \\
\hline average & 25.9 & 47.7 \\
\hline
\end{tabular}


Table 3: Univariate Tests

\begin{tabular}{|c|c|c|c|c|c|c|}
\hline \multirow[t]{2}{*}{ Variable } & \multicolumn{2}{|c|}{$\begin{array}{l}\text { Firms not reporting } \\
\text { EBITDA in the } \\
\text { annual report }\end{array}$} & \multicolumn{2}{|c|}{$\begin{array}{l}\text { Firms reporting } \\
\text { EBITDA in the } \\
\text { annual report }\end{array}$} & \multirow{2}{*}{$\begin{array}{c}\text { t-test } \\
\text { mean } \\
\text { differences }\end{array}$} & \multirow{2}{*}{ 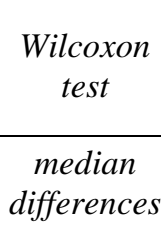 } \\
\hline & Average & Median & Average & Median & & \\
\hline $\mathrm{N} \mathrm{Obs}=15,895$ & & & & & $p$-value & $p$-value \\
\hline Market Cap (mln USD) & 12,044 & 2,343 & 4,923 & 1,989 & 0.000 & 0.000 \\
\hline Sales (mln USD) & 8,381 & 1,672 & 4,442 & 1,675 & 0.000 & 0.482 \\
\hline Assets (mln USD) & 23,541 & 2,885 & 5,610 & 2,132 & 0.000 & 0.000 \\
\hline ROA & 0.051 & 0.047 & 0.042 & 0.043 & 0.000 & 0.000 \\
\hline Loss firm & 0.110 & 0.000 & 0.160 & 0.000 & 0.000 & / \\
\hline Drop in earnings & 0.275 & 0.000 & 0.294 & 0.000 & 0.078 & 0.148 \\
\hline Market to Book & 3.000 & 2.154 & 3.060 & 2.181 & 0.494 & 0.184 \\
\hline Sales Growth & 0.085 & 0.048 & 0.077 & 0.049 & 0.124 & 0.410 \\
\hline Capital Intensity & 0.231 & 0.147 & 0.263 & 0.191 & 0.000 & 0.000 \\
\hline Intangibles & 0.177 & 0.101 & 0.269 & 0.241 & 0.000 & 0.000 \\
\hline Leverage & 0.337 & 0.325 & 0.444 & 0.423 & 0.000 & 0.000 \\
\hline Interest Exp & 0.023 & 0.012 & 0.034 & 0.018 & 0.000 & 0.000 \\
\hline Tax Rate & 0.240 & 0.316 & 0.222 & 0.322 & 0.066 & 0.030 \\
\hline Cycle & 0.055 & 0.151 & 0.176 & 0.143 & 0.000 & 0.166 \\
\hline Change in WC & -0.014 & -0.009 & 0.011 & 0.009 & 0.075 & 0.085 \\
\hline Forecast Miss & 0.309 & 0.000 & 0.345 & 0.000 & 0.001 & 0.001 \\
\hline Forecast Error & 0.004 & 0.001 & 0.005 & 0.002 & 0.000 & 0.000 \\
\hline Cash & 0.147 & 0.086 & 0.109 & 0.067 & 0.000 & 0.000 \\
\hline $\mathrm{R} \& \mathrm{D}$ & 0.033 & 0.000 & 0.015 & 0.000 & 0.000 & 0.000 \\
\hline Capex & 0.045 & 0.028 & 0.047 & 0.315 & 0.130 & 0.000 \\
\hline
\end{tabular}

This table shows mean and median values of firm characteristics for EBITDA-reporting firms and non-EBITDA reporting firms. Annual reports are considered in this table. Differences between means are tested for their significance by means of t-tests (2-sided) of which p-values are provided in column 6. Differences between medians are tested for their significance by means of Wilcoxon Rank Sum tests (2-sided) of which p-values are provided in column 7. All variables are defined in the Appendix. 
Table 4: EBITDA Disclosures - Main Analysis

Panel A: EBITDA Disclosure in Annual Reports

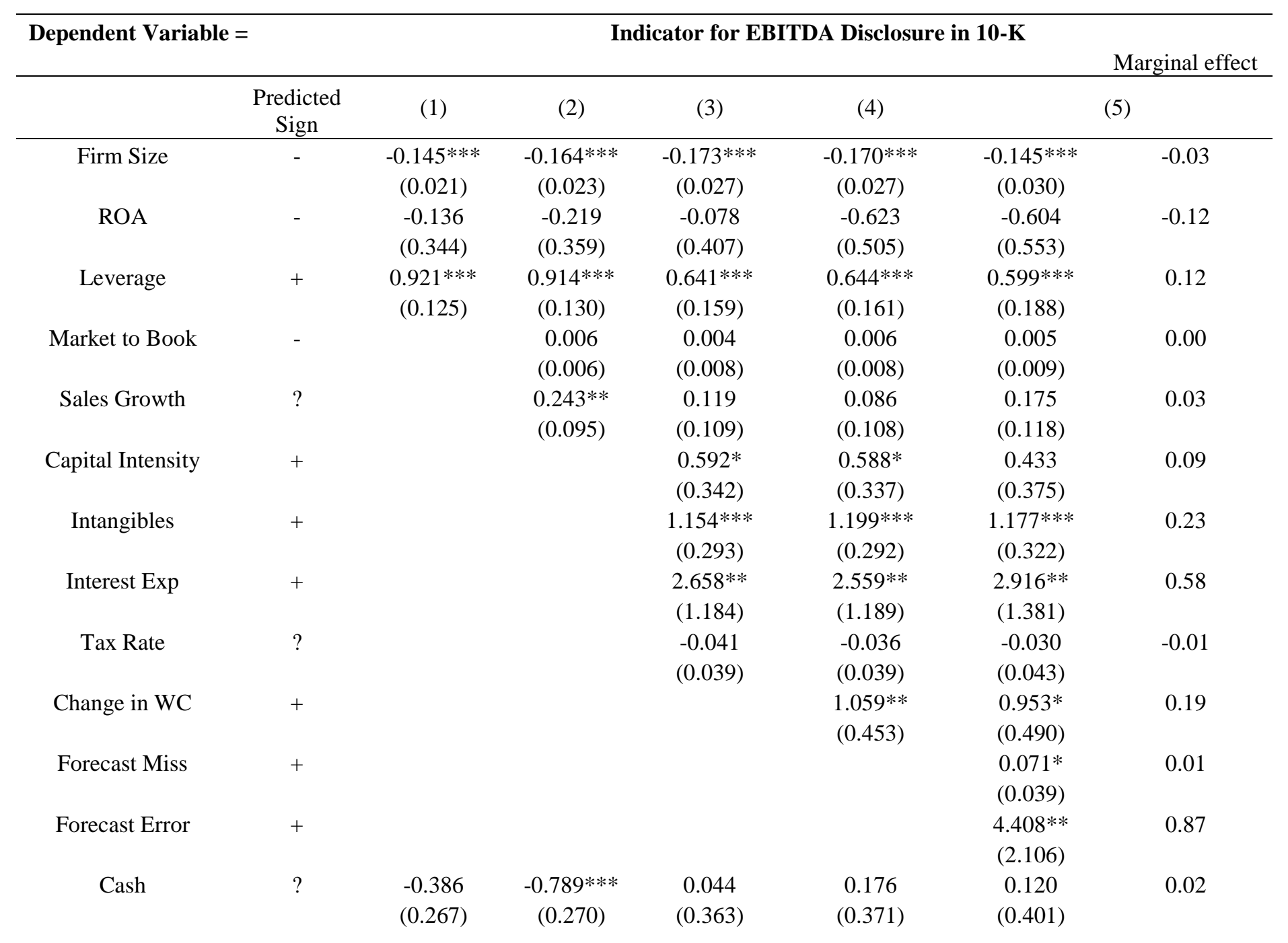




\begin{tabular}{cccccccc} 
R \& D & $?$ & $-3.435 * * *$ & $-3.517 * * *$ & $-4.514 * * *$ & $-4.577 * * *$ & $-4.531 * * *$ & -0.90 \\
& & $(0.761)$ & $(0.793)$ & $(0.927)$ & $(0.928)$ & $(0.963)$ & 0.648 \\
Capex & $?$ & 0.968 & 0.101 & 0.825 & 1.003 & $(0.910)$ & -13 \\
& & $(0.632)$ & $(0.636)$ & $(0.783)$ & $(0.776)$ & $-0.848^{* *}$ & $(0.330)$ \\
Constant & $?$ & $-0.513^{*}$ & -0.344 & $-0.807 * *$ & $-0.824 * *$ & $(0.314)$ & Included \\
& & $(0.275)$ & $(0.285)$ & $(0.315)$ & Included & Included \\
\hline Year Effects & Included & Included & Included & 10,295 & 8,688 \\
Industry Effects & Included & Included & Included & 0.175 & 0.165 \\
\hline Observations & 15,895 & 12,787 & 10,296 & & \\
\hline
\end{tabular}


Panel B: EBITDA Disclosure in Earnings Announcements

\begin{tabular}{|c|c|c|c|c|c|c|}
\hline \multicolumn{3}{|c|}{ Dependent Variable $=$} & \multicolumn{4}{|c|}{ Indicator for EBITDA Disclosure in Earnings Announcements } \\
\hline & & & & & \multicolumn{2}{|c|}{ Marginal effect } \\
\hline & $\begin{array}{l}\text { Predicted } \\
\text { Sign }\end{array}$ & (1) & (2) & (3) & & \\
\hline Firm Size & - & $\begin{array}{c}-0.177 * * * \\
(0.022)\end{array}$ & $\begin{array}{c}-0.186 * * * \\
(0.024)\end{array}$ & $\begin{array}{c}-0.202 * * * \\
(0.026)\end{array}$ & $\begin{array}{c}-0.201 * * * \\
(0.026)\end{array}$ & -0.04 \\
\hline ROA & - & $\begin{array}{c}-0.796 * * \\
(0.322)\end{array}$ & $\begin{array}{c}-1.055^{* * *} \\
(0.331)\end{array}$ & $\begin{array}{c}-0.746 * * \\
(0.344)\end{array}$ & $\begin{array}{c}-1.084 * * \\
(0.452)\end{array}$ & -0.24 \\
\hline Leverage & + & $\begin{array}{c}0.834 * * * \\
(0.120)\end{array}$ & $\begin{array}{c}0.798 * * * \\
-0.125\end{array}$ & $\begin{array}{c}0.636^{* * * *} \\
(0.147)\end{array}$ & $\begin{array}{c}0.633 * * * \\
(0.147)\end{array}$ & 0.14 \\
\hline Market to Book & - & & $\begin{array}{c}0.006 \\
(0.006)\end{array}$ & $\begin{array}{c}0.007 \\
(0.006)\end{array}$ & $\begin{array}{c}0.008 \\
(0.006)\end{array}$ & 0.00 \\
\hline Sales Growth & $?$ & & $\begin{array}{c}0.489 * * * \\
(0.091)\end{array}$ & $\begin{array}{c}0.300 * * * \\
(0.092)\end{array}$ & $\begin{array}{c}0.283 * * * \\
(0.092)\end{array}$ & 0.06 \\
\hline Capital Intensity & + & & & $\begin{array}{c}0.769 * * \\
(0.334)\end{array}$ & $\begin{array}{c}0.774 * * \\
(0.333)\end{array}$ & 0.17 \\
\hline Intangibles & + & & & $\begin{array}{c}1.607 * * * \\
(0.246)\end{array}$ & $\begin{array}{c}1.639 * * * \\
(0.246)\end{array}$ & 0.36 \\
\hline Interest Exp & + & & & $\begin{array}{c}2.003 * * \\
(1.015)\end{array}$ & $\begin{array}{l}1.938^{*} \\
(1.025)\end{array}$ & 0.43 \\
\hline Tax Rate & $?$ & & & $\begin{array}{c}0.032 \\
(0.036)\end{array}$ & $\begin{array}{c}0.036 \\
(0.036)\end{array}$ & 0.01 \\
\hline Change in WC & + & & & & $\begin{array}{c}0.626 \\
(0.421)\end{array}$ & 0.14 \\
\hline Cash & $?$ & $\begin{array}{c}0.021 \\
(0.246)\end{array}$ & $\begin{array}{l}-0.170 \\
(0.253)\end{array}$ & $\begin{array}{c}0.932 * * * \\
(0.326)\end{array}$ & $\begin{array}{c}1.019 * * * \\
(0.332)\end{array}$ & 0.23 \\
\hline$R \& D$ & $?$ & $\begin{array}{c}-3.580 * * * \\
(0.631)\end{array}$ & $\begin{array}{c}-4.078 * * * \\
(0.653)\end{array}$ & $\begin{array}{c}-4.947 * * * \\
(0.698)\end{array}$ & $\begin{array}{c}-5.032 * * * \\
(0.699)\end{array}$ & -1.11 \\
\hline Capex & $?$ & $\begin{array}{c}2.030 * * * \\
(0.576)\end{array}$ & $\begin{array}{c}1.331 * * \\
(0.621)\end{array}$ & $\begin{array}{c}2.279 * * * \\
(0.647)\end{array}$ & $\begin{array}{c}2.379 * * * \\
(0.645)\end{array}$ & 0.53 \\
\hline Constant & $?$ & -0.129 & -0.052 & $-0.537^{*}$ & $-0.534^{*}$ & \\
\hline
\end{tabular}




\begin{tabular}{ccccc} 
& $(0.230)$ & $(0.242)$ & $(0.279)$ & $(0.280)$ \\
\hline $\begin{array}{c}\text { Year Effects } \\
\text { Industry Effects }\end{array}$ & $\begin{array}{c}\text { Included } \\
\text { Included }\end{array}$ & $\begin{array}{c}\text { Included } \\
\text { Included }\end{array}$ & $\begin{array}{c}\text { Included } \\
\text { Included }\end{array}$ & $\begin{array}{c}\text { Included } \\
\text { Included }\end{array}$ \\
\hline $\begin{array}{c}\text { Observations } \\
\begin{array}{c}\text { Pseudo R- } \\
\text { squared }\end{array}\end{array}$ & 51,758 & 46,115 & 38,460 & 38,460 \\
& 0.184 & 0.183 & 0.203 & 0.204 \\
\hline
\end{tabular}

Table 4 presents probit regression analyses of EBITDA disclosure for a sample of S\&P1500 firms between 2005 and 2016. In Panel A, the dependent variable EBITDA is a dummy variable equal to one if a firm has mentioned at least three times "EBITDA" in the current year annual report, and zero otherwise. In Panel B, the dependent variable $E B I T D A$ is a dummy variable equal to one if a firm discloses "EBITDA" at least once in the current annual or quarterly earnings announcement, and zero otherwise. Annual reports and earnings announcements are extracted from EDGAR. All explanatory variables are measured for the current year. All variables are defined in the Appendix. Standard errors are presented below the coefficients in parentheses and are clustered by firm. *, **,*** denote significance at the $10 \%, 5 \%$ and $1 \%$ level (two-sided). 
Table 5: Changes in EBITDA disclosures

Panel A: EBITDA Disclosure in Annual Reports

\begin{tabular}{|c|c|c|c|c|c|c|}
\hline \multirow[t]{2}{*}{ Dependent Variable $=$} & \multirow[b]{2}{*}{$\begin{array}{l}\text { Predicted } \\
\text { Sign }\end{array}$} & \multicolumn{5}{|c|}{ Indicator for EBITDA Disclosure in $10-\mathrm{K}$} \\
\hline & & (1) & (2) & (3) & (4) & (5) \\
\hline EBITDA in Prior Year & + & $\begin{array}{c}2.681 * * * \\
(0.054)\end{array}$ & $\begin{array}{c}2.626 * * * \\
(0.057)\end{array}$ & $\begin{array}{c}2.552 * * * \\
(0.061)\end{array}$ & $\begin{array}{c}2.554 * * * \\
(0.061)\end{array}$ & $\begin{array}{c}2.571 * * * \\
(0.065)\end{array}$ \\
\hline Firm Size & - & $\begin{array}{c}-0.103 * * * \\
(0.015)\end{array}$ & $\begin{array}{c}-0.111 * * * \\
(0.017)\end{array}$ & $\begin{array}{c}-0.125 * * * \\
(0.020)\end{array}$ & $\begin{array}{c}-0.121 * * * \\
(0.020)\end{array}$ & $\begin{array}{c}-0.096 * * * \\
(0.022)\end{array}$ \\
\hline ROA & - & $\begin{array}{l}-0.239 \\
(0.302)\end{array}$ & $\begin{array}{l}-0.279 \\
(0.329)\end{array}$ & $\begin{array}{c}0.080 \\
(0.390)\end{array}$ & $\begin{array}{c}-0.591 \\
(0.439)\end{array}$ & $\begin{array}{l}-0.530 \\
(0.480)\end{array}$ \\
\hline Leverage & + & $\begin{array}{c}0.538 * * * \\
(0.085)\end{array}$ & $\begin{array}{c}0.502 * * * \\
(0.091)\end{array}$ & $\begin{array}{c}0.398 * * * \\
(0.113)\end{array}$ & $\begin{array}{c}0.400 * * * \\
(0.115)\end{array}$ & $\begin{array}{c}0.400 * * * \\
(0.115)\end{array}$ \\
\hline Market to Book & - & & $\begin{array}{c}0.005 \\
(0.006)\end{array}$ & $\begin{array}{c}0.003 \\
(0.007)\end{array}$ & $\begin{array}{c}0.005 \\
(0.007)\end{array}$ & $\begin{array}{c}0.009 \\
(0.007)\end{array}$ \\
\hline Sales Growth & $?$ & & $\begin{array}{c}0.131 \\
(0.118)\end{array}$ & $\begin{array}{c}0.044 \\
(0.135)\end{array}$ & $\begin{array}{c}0.003 \\
(0.136)\end{array}$ & $\begin{array}{c}0.017 \\
(0.152)\end{array}$ \\
\hline Capital Intensity & + & & & $\begin{array}{c}0.391 \\
(0.247)\end{array}$ & $\begin{array}{l}0.397 * \\
(0.245)\end{array}$ & $\begin{array}{c}0.371 \\
(0.261)\end{array}$ \\
\hline Intangibles & + & & & $\begin{array}{c}0.769 * * * \\
(0.198)\end{array}$ & $\begin{array}{c}0.828 * * * \\
(0.198)\end{array}$ & $\begin{array}{c}0.922 * * * \\
(0.219)\end{array}$ \\
\hline Interest Exp & + & & & $\begin{array}{c}1.133 \\
(0.841)\end{array}$ & $\begin{array}{c}1.036 \\
(0.850)\end{array}$ & $\begin{array}{c}1.740 * \\
(0.974)\end{array}$ \\
\hline Tax Rate & $?$ & & & $\begin{array}{l}-0.055 \\
(0.047)\end{array}$ & $\begin{array}{l}-0.049 \\
(0.046)\end{array}$ & $\begin{array}{c}-0.058 \\
(0.053)\end{array}$ \\
\hline Change in WC & + & & & & $\begin{array}{c}1.265^{* * * *} \\
(0.472)\end{array}$ & $\begin{array}{c}1.197 * * \\
(0.523)\end{array}$ \\
\hline Forecast Miss & + & & & & & $\begin{array}{l}0.089^{*} \\
(0.051)\end{array}$ \\
\hline Forecast Error & + & & & & & $\begin{array}{c}3.436 \\
(2.615)\end{array}$ \\
\hline Cash & $?$ & -0.238 & $-0.498 * *$ & -0.080 & 0.081 & 0.077 \\
\hline
\end{tabular}




\begin{tabular}{|c|c|c|c|c|c|c|}
\hline & & $(0.184)$ & $(0.195)$ & $(0.267)$ & $(0.273)$ & $(0.293)$ \\
\hline $\mathrm{R} \& \mathrm{D}$ & $?$ & $\begin{array}{c}-2.012 * * * \\
(0.496)\end{array}$ & $\begin{array}{c}-2.112 * * * \\
(0.521)\end{array}$ & $\begin{array}{c}-2.637 * * * \\
(0.598)\end{array}$ & $\begin{array}{c}-2.730 * * * \\
(0.595)\end{array}$ & $\begin{array}{c}-2.617 * * * \\
(0.613)\end{array}$ \\
\hline Capex & $?$ & $\begin{array}{c}0.461 \\
(0.498)\end{array}$ & $\begin{array}{l}-0.089 \\
(0.521)\end{array}$ & $\begin{array}{c}0.468 \\
(0.702)\end{array}$ & $\begin{array}{c}0.674 \\
(0.707)\end{array}$ & $\begin{array}{c}0.050 \\
(0.804)\end{array}$ \\
\hline Constant & $?$ & $\begin{array}{c}-1.211 * * * \\
(0.211) \\
\end{array}$ & $\begin{array}{c}-1.113 * * * \\
(0.219) \\
\end{array}$ & $\begin{array}{c}-1.317 * * * \\
(0.243) \\
\end{array}$ & $\begin{array}{c}-1.346^{* * *} * \\
(0.242) \\
\end{array}$ & $\begin{array}{c}-1.502 * * * \\
(0.267) \\
\end{array}$ \\
\hline Year Effects & & Included & Included & Included & Included & Included \\
\hline Industry Effects & & Included & Included & Included & Included & Included \\
\hline Observations & & 14,638 & 11,776 & 9,459 & 9,458 & 8,035 \\
\hline Pseudo R-squared & & 0.571 & 0.555 & 0.546 & 0.547 & 0.548 \\
\hline
\end{tabular}


Panel B: EBITDA Disclosure in Earnings Announcements

\begin{tabular}{|c|c|c|c|c|c|}
\hline \multirow[t]{2}{*}{ Dependent Variable $=$} & \multicolumn{5}{|c|}{ Indicator for EBITDA Disclosure in Earnings Announcements } \\
\hline & $\begin{array}{l}\text { Predicted } \\
\text { Sign }\end{array}$ & $(1)$ & $(2)$ & (3) & (4) \\
\hline EBITDA in Prior Year & + & $\begin{array}{c}2.228 * * * \\
(0.049)\end{array}$ & $\begin{array}{c}2.199 * * * \\
(0.052)\end{array}$ & $\begin{array}{c}2.113 * * * \\
(0.056)\end{array}$ & $\begin{array}{c}2.113 * * * \\
(0.056)\end{array}$ \\
\hline Firm Size & - & $\begin{array}{c}-0.110 * * * \\
(0.013)\end{array}$ & $\begin{array}{c}-0.113 * * * \\
(0.014)\end{array}$ & $\begin{array}{c}-0.122 * * * \\
(0.016)\end{array}$ & $\begin{array}{c}-0.121 * * * \\
(0.016)\end{array}$ \\
\hline ROA & - & $\begin{array}{c}-0.499 * * \\
(0.196)\end{array}$ & $\begin{array}{c}-0.644 * * * \\
(0.202)\end{array}$ & $\begin{array}{c}-0.470 * * \\
(0.213)\end{array}$ & $\begin{array}{c}-0.746 * * * \\
(0.277)\end{array}$ \\
\hline Leverage & + & $\begin{array}{c}0.486^{* * *} * \\
(0.068)\end{array}$ & $\begin{array}{c}0.469 * * * \\
(0.071)\end{array}$ & $\begin{array}{c}0.393 * * * \\
(0.085)\end{array}$ & $\begin{array}{c}0.390 * * * \\
(0.085)\end{array}$ \\
\hline Market to Book & - & & $\begin{array}{c}0.001 \\
(0.003)\end{array}$ & $\begin{array}{c}0.002 \\
(0.004)\end{array}$ & $\begin{array}{c}0.003 \\
(0.004)\end{array}$ \\
\hline Sales Growth & $?$ & & $\begin{array}{c}0.306 * * * \\
(0.054)\end{array}$ & $\begin{array}{c}0.182 * * * \\
(0.057)\end{array}$ & $\begin{array}{c}0.169 * * * \\
(0.056)\end{array}$ \\
\hline Capital Intensity & + & & & $\begin{array}{c}0.428 * * \\
(0.198)\end{array}$ & $\begin{array}{c}0.433 * * \\
(0.197)\end{array}$ \\
\hline Intangibles & + & & & $\begin{array}{c}0.939 * * * \\
(0.146)\end{array}$ & $\begin{array}{c}0.964 * * * \\
(0.145)\end{array}$ \\
\hline Interest Exp & + & & & $\begin{array}{c}0.993 * \\
(0.572)\end{array}$ & $\begin{array}{c}0.945 \\
(0.576)\end{array}$ \\
\hline Tax Rate & $?$ & & & $\begin{array}{c}0.023 \\
(0.024)\end{array}$ & $\begin{array}{c}0.026 \\
(0.023)\end{array}$ \\
\hline Change in WC & + & & & & $\begin{array}{l}0.502^{*} \\
(0.257)\end{array}$ \\
\hline Cash & $?$ & $\begin{array}{c}-0.019 \\
(0.143)\end{array}$ & $\begin{array}{l}-0.112 \\
(0.149)\end{array}$ & $\begin{array}{c}0.503 * * \\
(0.197)\end{array}$ & $\begin{array}{c}0.573 * * * \\
(0.199)\end{array}$ \\
\hline $\mathrm{R} \& \mathrm{D}$ & $?$ & $\begin{array}{c}-2.150 * * * \\
(0.389)\end{array}$ & $\begin{array}{c}-2.452 * * * \\
(0.403)\end{array}$ & $\begin{array}{c}-3.001 * * * \\
(0.433)\end{array}$ & $\begin{array}{c}-3.070 * * * \\
(0.433)\end{array}$ \\
\hline Capex & $?$ & $\begin{array}{c}1.197 * * * \\
(0.334)\end{array}$ & $\begin{array}{c}0.787 * * \\
(0.359)\end{array}$ & $\begin{array}{c}1.320 * * * \\
(0.379)\end{array}$ & $\begin{array}{c}1.397 * * * \\
(0.379)\end{array}$ \\
\hline
\end{tabular}




\begin{tabular}{|c|c|c|c|c|c|}
\hline Constant & $?$ & $\begin{array}{c}-0.947 * * * \\
(0.140) \\
\end{array}$ & $\begin{array}{c}-0.909 * * * \\
(0.149)\end{array}$ & $\begin{array}{c}-1.172 * * * \\
(0.171) \\
\end{array}$ & $\begin{array}{c}-1.170 * * * \\
(0.171)\end{array}$ \\
\hline Year Effects & & Included & Included & Included & Included \\
\hline Industry Effects & & Included & Included & Included & Included \\
\hline Observations & & 51,758 & 46,115 & 38,460 & 38,460 \\
\hline Pseudo R-squared & & 0.505 & 0.497 & 0.490 & 0.491 \\
\hline
\end{tabular}

Table 5 presents probit regression analyses of EBITDA disclosure for a sample of S\&P1500 firms between 2005 and 2016. In Panel A, the dependent variable EBITDA is a dummy variable equal to one if a firm has mentioned at least three times "EBITDA" in the current year annual report, and zero otherwise. In Panel B, the dependent variable $E B I T D A$ is a dummy variable equal to one if a firm discloses "EBITDA" at least once in the current annual or quarterly earnings announcement, and zero otherwise. EBITDA in Prior Year is a dummy variable equal to one if a firm has mentioned at least three times "EBITDA" in the report of the previous fiscal year, and zero otherwise (Panel A). EBITDA in Prior Year is a dummy variable equal to one if a firm has mentioned at least one time "EBITDA" in the previous earnings announcement, and zero otherwise (Panel B). Annual reports and earnings announcements are extracted from EDGAR. All explanatory variables are measured for the current year. All variables are defined in the Appendix. Standard errors are presented below the coefficients in parentheses and are clustered by firm. *, **, *** denote significance at the $10 \%, 5 \%$ and $1 \%$ level (twosided). 
Table 6: Intensity of EBITDA disclosures

Panel A: Intensity of EBITDA Disclosure in Annual Reports

\begin{tabular}{|c|c|c|c|c|c|c|c|}
\hline \multirow{2}{*}{\multicolumn{2}{|c|}{$\begin{array}{l}\text { Dependent Variable }= \\
\text { Sample }=\end{array}$}} & \multicolumn{6}{|c|}{ EBITDA Count in 10 -K } \\
\hline & & \multicolumn{4}{|c|}{ All Firms } & \multicolumn{2}{|c|}{ Only EBITDA disclosing Firms } \\
\hline & $\begin{array}{l}\text { Predicted } \\
\text { Sign }\end{array}$ & (1) & (2) & (3) & (4) & (5) & (6) \\
\hline Firm Size & - & $\begin{array}{c}-0.338 * * * \\
(0.005)\end{array}$ & $\begin{array}{c}-0.412 * * * \\
(0.006)\end{array}$ & $\begin{array}{c}-0.411 * * * \\
(0.006)\end{array}$ & $\begin{array}{c}-0.377 * * * \\
(0.007)\end{array}$ & $\begin{array}{c}0.023 \\
(0.035)\end{array}$ & $\begin{array}{c}0.010 \\
(0.038)\end{array}$ \\
\hline ROA & - & $\begin{array}{l}-0.141 \\
(0.206)\end{array}$ & $\begin{array}{c}0.248 \\
(0.222)\end{array}$ & $\begin{array}{l}-0.022 \\
(0.236)\end{array}$ & $\begin{array}{c}0.133 \\
(0.266)\end{array}$ & $\begin{array}{l}-0.626 \\
(0.388)\end{array}$ & $\begin{array}{l}-0.118 \\
(0.621)\end{array}$ \\
\hline Leverage & + & $\begin{array}{c}2.002 * * * \\
(0.064)\end{array}$ & $\begin{array}{c}1.472 * * * \\
(0.075)\end{array}$ & $\begin{array}{c}1.473 * * * \\
(0.075)\end{array}$ & $\begin{array}{c}1.419 * * * \\
(0.086)\end{array}$ & $\begin{array}{c}0.444 * * * \\
(0.126)\end{array}$ & $\begin{array}{c}0.436 * * * \\
(0.144)\end{array}$ \\
\hline Market to Book & - & & $\begin{array}{c}0.011 * * \\
(0.005)\end{array}$ & $\begin{array}{c}0.012 * * \\
(0.005)\end{array}$ & $\begin{array}{c}0.006 \\
(0.006)\end{array}$ & & $\begin{array}{c}0.011 \\
(0.007)\end{array}$ \\
\hline Sales Growth & $?$ & & $\begin{array}{c}0.146 * * \\
(0.057)\end{array}$ & $\begin{array}{c}0.129 * * \\
(0.058)\end{array}$ & $\begin{array}{l}0.208 * * * \\
(0.062)\end{array}$ & & $\begin{array}{c}0.004 \\
(0.123)\end{array}$ \\
\hline Capital Intensity & + & & $\begin{array}{c}1.128 * * * \\
(0.100)\end{array}$ & $\begin{array}{c}1.126 * * * \\
(0.100)\end{array}$ & $\begin{array}{c}0.895 * * * \\
(0.112)\end{array}$ & & $\begin{array}{l}0.750 * \\
(0.436)\end{array}$ \\
\hline Intangibles & + & & $\begin{array}{c}2.452 * * * \\
(0.092)\end{array}$ & $\begin{array}{c}2.472 * * * \\
(0.092)\end{array}$ & $\begin{array}{c}2.338 * * * \\
(0.101)\end{array}$ & & $\begin{array}{c}0.116 \\
(0.323)\end{array}$ \\
\hline Interest Exp & + & & $\begin{array}{c}4.790 * * * \\
(0.560)\end{array}$ & $\begin{array}{c}4.736 * * * \\
(0.560)\end{array}$ & $\begin{array}{l}5.541 * * * \\
(0.667)\end{array}$ & & $\begin{array}{l}2.082 * \\
(1.284)\end{array}$ \\
\hline Tax Rate & $?$ & & $\begin{array}{l}-0.047 * \\
(0.028)\end{array}$ & $\begin{array}{c}-0.044 \\
(0.028)\end{array}$ & $\begin{array}{c}-0.004 \\
(0.032)\end{array}$ & & $\begin{array}{c}-0.060 \\
(0.039)\end{array}$ \\
\hline Change in WC & + & & & $\begin{array}{c}0.540 * * * \\
(0.132)\end{array}$ & $\begin{array}{c}0.599 * * * \\
(0.146)\end{array}$ & & $\begin{array}{c}0.142 \\
(0.675)\end{array}$ \\
\hline Forecast Miss & + & & & & $\begin{array}{c}0.093 * * * \\
(0.035)\end{array}$ & & \\
\hline Forecast Error & + & & & & $\begin{array}{c}8.387 * * * \\
(1.064)\end{array}$ & & \\
\hline Cash & $?$ & $-1.038 * * *$ & -0.209 & -0.140 & $-0.322 * *$ & $0.607 * *$ & $0.859^{*}$ \\
\hline
\end{tabular}




\begin{tabular}{|c|c|c|c|c|c|c|c|}
\hline & & $(0.132)$ & $(0.144)$ & $(0.145)$ & $(0.158)$ & $(0.296)$ & $(0.509)$ \\
\hline$R \& D$ & $?$ & $\begin{array}{c}-6.596 * * * \\
(0.283)\end{array}$ & $\begin{array}{c}-7.506^{* * *} \\
(0.303)\end{array}$ & $\begin{array}{c}-7.530 * * * \\
(0.303)\end{array}$ & $\begin{array}{c}-7.536 * * * \\
(0.326)\end{array}$ & $\begin{array}{c}-0.075 \\
(1.101)\end{array}$ & $\begin{array}{l}-0.093 \\
(1.314)\end{array}$ \\
\hline Capex & $?$ & $\begin{array}{c}2.761 * * * \\
(0.331)\end{array}$ & $\begin{array}{c}2.339 * * * \\
(0.403)\end{array}$ & $\begin{array}{c}2.426^{* * * *} \\
(0.403)\end{array}$ & $\begin{array}{c}1.759 * * * \\
(0.445)\end{array}$ & $\begin{array}{c}0.176 \\
(0.636)\end{array}$ & $\begin{array}{l}-1.234 \\
(0.846)\end{array}$ \\
\hline Constant & $?$ & $\begin{array}{c}-12.562 * * * \\
(0.043)\end{array}$ & $\begin{array}{c}-11.372 * * * \\
(0.047)\end{array}$ & $\begin{array}{c}-11.375^{* * *} \\
(0.047)\end{array}$ & $\begin{array}{c}-11.420 * * * \\
(0.051)\end{array}$ & $\begin{array}{c}1.909 * * * \\
(0.322)\end{array}$ & $\begin{array}{c}1.626 * * * \\
(0.404)\end{array}$ \\
\hline Year Effects & & Included & Included & Included & Included & Included & Included \\
\hline Industry Effects & & Included & Included & Included & Included & Included & Included \\
\hline Observations & & 15,298 & 10,108 & 10,106 & 8,929 & 2,113 & 1,553 \\
\hline Adjusted R-squared & & & & & & 0.237 & 0.256 \\
\hline Pseudo R-squared & & 0.103 & 0.102 & 0.102 & 0.0977 & & \\
\hline
\end{tabular}


Panel B: Intensity of EBITDA Disclosure in Earnings Announcements

\begin{tabular}{|c|c|c|c|c|c|c|}
\hline \multirow{3}{*}{$\begin{array}{l}\text { Dependent Variable = } \\
\text { Sample }=\end{array}$} & \multicolumn{6}{|c|}{ EBITDA Count in Earnings Announcements } \\
\hline & \multirow[b]{2}{*}{$\begin{array}{l}\text { Pred. } \\
\text { Sign }\end{array}$} & \multicolumn{3}{|c|}{ All Firms } & \multicolumn{2}{|c|}{ Only EBITDA disclosing Firms } \\
\hline & & (1) & $(2)$ & (3) & (4) & $(5)$ \\
\hline Firm Size & - & $\begin{array}{c}-0.555^{* * * *} \\
(0.067)\end{array}$ & $\begin{array}{c}-0.589 * * * \\
(0.073)\end{array}$ & $\begin{array}{c}-0.585^{* * *} \\
(0.074)\end{array}$ & $\begin{array}{c}-0.168 * * * \\
(0.049)\end{array}$ & $\begin{array}{c}-0.160 * * * \\
(0.051)\end{array}$ \\
\hline ROA & - & $\begin{array}{c}-2.573 * * * \\
(0.985)\end{array}$ & $\begin{array}{c}-2.240 * * \\
(0.993)\end{array}$ & $\begin{array}{c}-3.234 * * \\
(1.298)\end{array}$ & $\begin{array}{l}-0.759 \\
(0.613)\end{array}$ & $\begin{array}{l}-0.635 \\
(0.878)\end{array}$ \\
\hline Leverage & + & $\begin{array}{c}2.623 * * * \\
(0.346)\end{array}$ & $\begin{array}{c}1.861 * * * \\
(0.392)\end{array}$ & $\begin{array}{l}1.852 * * * \\
(0.392)\end{array}$ & $\begin{array}{l}0.585 * * * \\
(0.224)\end{array}$ & $\begin{array}{c}0.208 \\
(0.243)\end{array}$ \\
\hline Market to Book & - & & $\begin{array}{c}0.017 \\
(0.016)\end{array}$ & $\begin{array}{c}0.019 \\
(0.016)\end{array}$ & & $\begin{array}{c}0.005 \\
(0.009)\end{array}$ \\
\hline Sales Growth & $?$ & & $\begin{array}{l}0.922 * * * \\
(0.253)\end{array}$ & $\begin{array}{l}0.873 * * * \\
(0.251)\end{array}$ & & $\begin{array}{c}0.176 \\
(0.200)\end{array}$ \\
\hline Capital Intensity & + & & $\begin{array}{c}2.376 * * * \\
(0.911)\end{array}$ & $\begin{array}{c}2.377 * * * \\
(0.910)\end{array}$ & & $\begin{array}{c}0.515 \\
(0.578)\end{array}$ \\
\hline Intangibles & + & & $\begin{array}{c}4.736 * * * \\
(0.693)\end{array}$ & $\begin{array}{c}4.820 * * * \\
(0.692)\end{array}$ & & $\begin{array}{l}0.919 * \\
(0.476)\end{array}$ \\
\hline Interest Exp & + & & $\begin{array}{l}6.711 * * \\
(2.697)\end{array}$ & $\begin{array}{l}6.529 * * \\
(2.724)\end{array}$ & & $\begin{array}{c}7.622 * * * \\
(2.030)\end{array}$ \\
\hline Tax Rate & $?$ & & $\begin{array}{c}0.054 \\
(0.100)\end{array}$ & $\begin{array}{c}0.064 \\
(0.099)\end{array}$ & & $\begin{array}{l}-0.035 \\
(0.056)\end{array}$ \\
\hline Change in WC & + & & & $\begin{array}{c}1.836 \\
(1.184)\end{array}$ & & $\begin{array}{c}0.115 \\
(0.786)\end{array}$ \\
\hline Cash & $?$ & $\begin{array}{c}0.309 \\
(0.753)\end{array}$ & $\begin{array}{c}3.129 * * * \\
(0.953)\end{array}$ & $\begin{array}{l}3.378 * * * \\
(0.968)\end{array}$ & $\begin{array}{c}0.568 \\
(0.489)\end{array}$ & $\begin{array}{l}1.437 * * \\
(0.640)\end{array}$ \\
\hline$R \& D$ & $?$ & $\begin{array}{c}-11.718 * * * \\
(2.017)\end{array}$ & $\begin{array}{c}-15.248 * * * \\
(2.080)\end{array}$ & $\begin{array}{c}-15.488 * * * \\
(2.082)\end{array}$ & $\begin{array}{c}0.584 \\
(1.753)\end{array}$ & $\begin{array}{l}-0.700 \\
(1.828)\end{array}$ \\
\hline Capex & $?$ & $\begin{array}{c}6.583 * * * \\
(1.760)\end{array}$ & $\begin{array}{c}6.983 * * * \\
(1.826)\end{array}$ & $\begin{array}{c}7.278 * * * \\
(1.826)\end{array}$ & $\begin{array}{c}2.710 * * \\
(1.086)\end{array}$ & $\begin{array}{l}2.020 * \\
(1.184)\end{array}$ \\
\hline Constant & $?$ & $-12.562 * * *$ & $-11.372 * * *$ & $-11.375^{* * *}$ & $1.909 * * *$ & $1.626 * * *$ \\
\hline
\end{tabular}




\begin{tabular}{cccccc} 
& $(0.043)$ & $(0.047)$ & $(0.047)$ & $(0.322)$ & $(0.404)$ \\
\hline Year Effects & Included & Included & Included & Included & Included \\
Included
\end{tabular}

Table 6 presents Tobit regression analyses with left censoring at zero of EBITDA disclosures for a sample of S\&P1500 firms between 2005 and 2016 in both Panel A (Specifications (1)-(4)) and Panel B (Specifications (1)-(3)). The remaining specifications are tested as OLS regression analyses. The dependent variable EBITDA Count is the natural log of 1 plus the number of times "EBITDA" is mentioned in the annual report (in Panel A) and in the earnings announcement (in Panel B). Annual reports and earnings announcements are extracted from EDGAR. All explanatory variables are measured for the current year. All variables are defined in the Appendix. Standard errors are presented below the coefficients in parentheses and are clustered by firm. *, **, *** denote significance at the $10 \%, 5 \%$ and $1 \%$ level (two-sided). 
Table 7: Adjusted EBITDA disclosures

\begin{tabular}{|c|c|c|c|c|c|c|c|}
\hline & & \multicolumn{4}{|c|}{ Adjusted EBITDA Disclosures in 10-K } & \multicolumn{2}{|c|}{$\begin{array}{c}\text { Adjusted EBITDA Disclosures in Earnings } \\
\text { Announcements }\end{array}$} \\
\hline \multicolumn{2}{|c|}{$\begin{array}{l}\text { Dependent Variable is an } \\
\text { Indicator for disclosure of: }\end{array}$} & $\begin{array}{l}\text { "Adjusted } \\
\text { EBITDA" }\end{array}$ & "EBITDAR" & $\begin{array}{l}\text { Either "Adjusted } \\
\text { EBITDA" or } \\
\text { "EBITDAR" }\end{array}$ & $\begin{array}{l}\text { Either "Adjusted } \\
\text { EBITDA" or } \\
\text { "EBITDAR" }\end{array}$ & $\begin{array}{l}\text { Either "Adjusted } \\
\text { EBITDA" or } \\
\text { "EBITDAR" }\end{array}$ & $\begin{array}{l}\text { Either "Adjusted } \\
\text { EBITDA" or } \\
\text { "EBITDAR" }\end{array}$ \\
\hline \multirow[t]{2}{*}{ Sample $=$} & & All Firms & All Firms & All Firms & $\begin{array}{l}\text { Only EBITDA } \\
\text { disclosing Firms }\end{array}$ & All Firms & $\begin{array}{l}\text { Only EBITDA } \\
\text { disclosing Firms }\end{array}$ \\
\hline & $\begin{array}{l}\text { Pred. } \\
\text { Sign }\end{array}$ & (1) & (2) & (3) & (4) & $(5)$ & (6) \\
\hline Firm Size & - & $\begin{array}{c}-0.099 * * * \\
(0.029)\end{array}$ & $\begin{array}{l}-0.028 \\
(0.038)\end{array}$ & $\begin{array}{l}-0.103 * * * \\
(0.028)\end{array}$ & $\begin{array}{l}-0.107 * \\
(0.059)\end{array}$ & $\begin{array}{c}-0.183 * * * \\
(0.029)\end{array}$ & $\begin{array}{c}-0.216 * * * \\
(0.052)\end{array}$ \\
\hline ROA & - & $\begin{array}{c}-1.229 * * * \\
(0.378)\end{array}$ & $\begin{array}{c}-1.143^{* *} \\
(0.474)\end{array}$ & $\begin{array}{c}-1.213 * * * \\
(0.376)\end{array}$ & $\begin{array}{c}-1.784 * * \\
(0.850)\end{array}$ & $\begin{array}{c}-1.602 * * * \\
(0.355)\end{array}$ & $\begin{array}{c}-2.082 * * * \\
(0.689)\end{array}$ \\
\hline Leverage & + & $\begin{array}{l}0.570 * * * \\
(0.152)\end{array}$ & $\begin{array}{c}0.546^{* * *} \\
(0.195)\end{array}$ & $\begin{array}{c}0.628 * * * \\
(0.152)\end{array}$ & $\begin{array}{c}0.287 \\
(0.292)\end{array}$ & $\begin{array}{c}0.776^{* * * *} \\
(0.166)\end{array}$ & $\begin{array}{c}0.610 * * \\
(0.256)\end{array}$ \\
\hline Market to Book & - & $\begin{array}{c}0.005 \\
(0.007)\end{array}$ & $\begin{array}{l}-0.012 \\
(0.009)\end{array}$ & $\begin{array}{c}0.002 \\
(0.007)\end{array}$ & $\begin{array}{c}0.013 \\
(0.013)\end{array}$ & $\begin{array}{c}0.003 \\
(0.007)\end{array}$ & $\begin{array}{c}0.004 \\
(0.010)\end{array}$ \\
\hline Sales Growth & $?$ & $\begin{array}{c}0.479 * * * \\
(0.102)\end{array}$ & $\begin{array}{c}0.531 * * * \\
(0.120)\end{array}$ & $\begin{array}{c}0.447 * * * \\
(0.101)\end{array}$ & $\begin{array}{c}0.345 \\
(0.248)\end{array}$ & $\begin{array}{c}0.347 * * * \\
(0.101)\end{array}$ & $\begin{array}{c}0.607 * * * \\
(0.204)\end{array}$ \\
\hline Capital Intensity & + & $\begin{array}{c}0.526 \\
(0.385)\end{array}$ & $\begin{array}{c}0.342 \\
(0.448)\end{array}$ & $\begin{array}{c}0.742 * * \\
(0.370)\end{array}$ & $\begin{array}{l}1.483^{*} \\
(0.769)\end{array}$ & $\begin{array}{c}0.752 * * \\
(0.341)\end{array}$ & $\begin{array}{c}0.399 \\
(0.563)\end{array}$ \\
\hline Intangibles & + & $\begin{array}{c}1.021 * * * \\
(0.271)\end{array}$ & $\begin{array}{c}0.824 * * * \\
(0.301)\end{array}$ & $\begin{array}{c}1.106^{* * *} \\
(0.268)\end{array}$ & $\begin{array}{c}0.340 \\
(0.543)\end{array}$ & $\begin{array}{c}1.259 * * * \\
(0.283)\end{array}$ & $\begin{array}{c}0.459 \\
(0.483)\end{array}$ \\
\hline Interest Exp & + & $\begin{array}{c}0.078 \\
(1.211)\end{array}$ & $\begin{array}{l}-2.143 \\
(1.470)\end{array}$ & $\begin{array}{l}-0.209 \\
(1.194)\end{array}$ & $\begin{array}{l}-2.112 \\
(2.216)\end{array}$ & $\begin{array}{c}1.694 \\
(1.174)\end{array}$ & $\begin{array}{c}2.413 \\
(2.016)\end{array}$ \\
\hline Tax Rate & $?$ & $\begin{array}{c}-0.058 \\
(0.038)\end{array}$ & $\begin{array}{c}-0.017 \\
(0.050)\end{array}$ & $\begin{array}{c}-0.047 \\
(0.038)\end{array}$ & $\begin{array}{c}-0.045 \\
(0.066)\end{array}$ & $\begin{array}{c}0.023 \\
(0.040)\end{array}$ & $\begin{array}{l}-0.032 \\
(0.064)\end{array}$ \\
\hline Cash & $?$ & $\begin{array}{c}1.181 * * * \\
(0.347)\end{array}$ & $\begin{array}{c}1.413 * * * \\
(0.371)\end{array}$ & $\begin{array}{c}1.303 * * * \\
(0.341)\end{array}$ & $\begin{array}{l}1.539 * \\
(0.805)\end{array}$ & $\begin{array}{c}1.087 * * * \\
(0.363)\end{array}$ & $\begin{array}{l}1.508 * * \\
(0.635)\end{array}$ \\
\hline$R \& D$ & $?$ & $-1.590 * *$ & -0.148 & $-1.494 * *$ & 3.350 & $-4.564 * * *$ & 3.079 \\
\hline
\end{tabular}




\begin{tabular}{|c|c|c|c|c|c|c|c|}
\hline & & $(0.700)$ & $(0.766)$ & $(0.692)$ & $(2.318)$ & $(0.766)$ & $(1.937)$ \\
\hline \multirow[t]{2}{*}{ Capex } & $?$ & 0.693 & 0.842 & 0.581 & -0.348 & $2.089 * * *$ & 0.150 \\
\hline & & $(0.765)$ & $(0.999)$ & $(0.761)$ & (1.616) & $(0.735)$ & $(1.122)$ \\
\hline \multirow[t]{2}{*}{ Constant } & $?$ & $-0.962 * * *$ & $-1.937 * * *$ & $-1.003 * * *$ & -0.455 & $-1.251 * * *$ & 0.614 \\
\hline & & $(0.316)$ & $(0.417)$ & $(0.312)$ & $(0.689)$ & $(0.336)$ & $(0.630)$ \\
\hline Year Effects & & Included & Included & Included & Included & Included & Included \\
\hline Industry Effects & & Included & Included & Included & Included & Included & Included \\
\hline Observations & & 10,339 & 10,038 & 10,500 & 1,518 & 38,346 & 5,761 \\
\hline Pseudo R-squared & & 0.104 & 0.115 & 0.097 & 0.145 & 0.236 & 0.204 \\
\hline
\end{tabular}

Table 7 presents probit regression analyses of Adjusted EBITDA disclosures for a sample of S\&P1500 firms between 2005 and 2016. In Specifications (1)-(4) show results for Adjusted EBITDA disclosures in annual reports and Specifications (5) and (6) in earnings announcement reports. In Specification (1), the dependent variable is a dummy variable equal to one if a firm has mentioned at least one time "Adjusted EBITDA" in the current year annual report, and zero otherwise. In Specification (2), the dependent variable is a dummy variable equal to one if a firm has mentioned at least one time "EBITDAR" in the current year annual report, and zero otherwise. In Specifications (3) and (4), the dependent variable is a dummy variable equal to one if a firm has mentioned at least one time either "Adjusted EBITDA" or "EBITDAR" in the current year annual report, and zero otherwise. In Specifications (5) and (6), the dependent variable is a dummy variable equal to one if a firm has mentioned at least one time either "Adjusted EBITDA" or "EBITDAR" in the current annual or quarterly earnings announcement, and zero otherwise. Specifications (4) and (6) only include firm observations which have disclosed at least once "EBITDA" in their annual report or earnings announcement. Annual reports and earnings announcements are extracted from EDGAR. All explanatory variables are measured for the current year. All variables are defined in the Appendix. Standard errors are presented below the coefficients in parentheses and are clustered by firm. $*, * * * * *$ denote significance at the $10 \%, 5 \%$ and $1 \%$ level (two-sided). 
Table 8: EBITA and EBIT disclosures

Panel A: EBITA and EBIT Disclosure in Annual Reports

\begin{tabular}{|c|c|c|c|c|}
\hline \multirow[t]{2}{*}{ Dependent Variable $=$} & \multicolumn{2}{|c|}{$\begin{array}{c}\text { Indicator for EBITA } \\
\text { Disclosure in 10-K }\end{array}$} & \multicolumn{2}{|c|}{$\begin{array}{l}\text { Indicator for EBIT } \\
\text { Disclosure in } 10-K\end{array}$} \\
\hline & $(1)$ & $(2)$ & (3) & $(4)$ \\
\hline \multirow[t]{2}{*}{ Firm Size } & -0.010 & -0.060 & 0.008 & 0.002 \\
\hline & $(0.036)$ & $(0.041)$ & $(0.028)$ & $(0.032)$ \\
\hline \multirow[t]{2}{*}{ ROA } & $-1.130 * *$ & -1.022 & -0.246 & 0.306 \\
\hline & $(0.531)$ & $(1.127)$ & $(0.456)$ & $(0.753)$ \\
\hline \multirow[t]{2}{*}{ Leverage } & $0.419 * *$ & $0.448 *$ & $0.427 * *$ & $0.531 * *$ \\
\hline & $(0.174)$ & $(0.258)$ & $(0.177)$ & $(0.237)$ \\
\hline \multirow[t]{2}{*}{ Market to Book } & -0.004 & -0.015 & 0.006 & 0.005 \\
\hline & $(0.008)$ & $(0.013)$ & $(0.008)$ & $(0.011)$ \\
\hline \multirow[t]{2}{*}{ Sales Growth } & $0.679 * * *$ & $0.620 * * *$ & $0.196^{*}$ & 0.049 \\
\hline & $(0.122)$ & $(0.159)$ & $(0.108)$ & $(0.130)$ \\
\hline \multirow[t]{2}{*}{ Capital Intensity } & -0.128 & 0.081 & -0.344 & -0.315 \\
\hline & $(0.379)$ & $(0.834)$ & $(0.302)$ & $(0.384)$ \\
\hline \multirow[t]{2}{*}{ Intangibles } & $0.611 * *$ & $0.517 *$ & 0.274 & 0.099 \\
\hline & $(0.264)$ & $(0.373)$ & $(0.263)$ & $(0.335)$ \\
\hline \multirow[t]{2}{*}{ Interest Exp } & -0.277 & -0.378 & -0.939 & -1.314 \\
\hline & $(1.333)$ & $(2.023)$ & $(1.401)$ & $(2.240)$ \\
\hline \multirow[t]{2}{*}{ Tax Rate } & -0.062 & 0.086 & 0.046 & $0.158 * *$ \\
\hline & $(0.052)$ & $(0.130)$ & $(0.046)$ & $(0.069)$ \\
\hline \multirow[t]{2}{*}{ Change in WC } & & 0.286 & & 0.301 \\
\hline & & $(0.730)$ & & $(0.613)$ \\
\hline \multirow[t]{2}{*}{ Forecast Miss } & & $0.182 * * *$ & & 0.030 \\
\hline & & $(0.069)$ & & $(0.046)$ \\
\hline \multirow[t]{2}{*}{ Forecast Error } & & 0.590 & & -2.058 \\
\hline & & $(3.441)$ & & $(3.150)$ \\
\hline \multirow[t]{2}{*}{ Cash } & $1.039 * * *$ & $1.365^{* * *}$ & $0.611^{*}$ & 0.537 \\
\hline & $(0.365)$ & $(0.406)$ & $(0.336)$ & $(0.409)$ \\
\hline \multirow[t]{2}{*}{$\mathrm{R} \& \mathrm{D}$} & 0.405 & $1.276^{*}$ & -0.060 & 0.330 \\
\hline & $(0.748)$ & $(0.775)$ & $(0.660)$ & $(0.754)$ \\
\hline \multirow[t]{2}{*}{ Capex } & 0.741 & 0.699 & 0.731 & 0.575 \\
\hline & $(0.905)$ & $(1.883)$ & $(0.742)$ & $(0.960)$ \\
\hline \multirow[t]{2}{*}{ Constant } & $-1.845^{* * *}$ & $-2.164 * * *$ & $-1.623 * * *$ & $-1.928 * * *$ \\
\hline & $(0.284)$ & $(0.294)$ & $(0.228)$ & $(0.260)$ \\
\hline Year Effects & Included & Included & Included & Included \\
\hline Observations & 10,573 & 9,038 & 10,573 & 9,038 \\
\hline Pseudo R-squared & 0.0720 & 0.130 & 0.0192 & 0.0235 \\
\hline
\end{tabular}


Panel B: EBITA and EBIT Disclosure in Earnings Announcements

\begin{tabular}{|c|c|c|c|c|}
\hline \multirow[t]{2}{*}{ Dependent Variable = } & \multicolumn{2}{|c|}{$\begin{array}{c}\text { Indicator for EBITA } \\
\text { Disclosure in Earnings } \\
\text { Announcements } \\
\end{array}$} & \multicolumn{2}{|c|}{$\begin{array}{c}\text { Indicator for EBIT } \\
\text { Disclosure in Earnings } \\
\text { Announcements } \\
\end{array}$} \\
\hline & (1) & (2) & (3) & (4) \\
\hline \multirow[t]{2}{*}{ Firm Size } & -0.072 & -0.082 & $0.197 * *$ & $0.222 * *$ \\
\hline & $(0.086)$ & $(0.094)$ & $(0.08)$ & $(0.094)$ \\
\hline \multirow[t]{2}{*}{ ROA } & $-1.262 *$ & -1.442 & 0.427 & 0.438 \\
\hline & $(0.716)$ & $(0.969)$ & $(0.567)$ & $(0.753)$ \\
\hline \multirow[t]{2}{*}{ Leverage } & $0.958 * * *$ & $1.090 * * *$ & 0.364 & 0.421 \\
\hline & $(0.343)$ & $(0.370)$ & $(0.257)$ & $(0.281)$ \\
\hline \multirow[t]{2}{*}{ Market to Book } & -0.020 & -0.024 & 0.013 & 0.013 \\
\hline & $(0.018)$ & $(0.021)$ & $(0.008)$ & $(0.009)$ \\
\hline \multirow[t]{2}{*}{ Sales Growth } & 0.043 & -0.011 & $-0.581 * * *$ & $-0.594 * * *$ \\
\hline & $(0.293)$ & $(0.311)$ & $(0.174)$ & $(0.180)$ \\
\hline \multirow[t]{2}{*}{ Capital Intensity } & -0.630 & -0.590 & -0.459 & -0.594 \\
\hline & $(0.890)$ & $(0.922)$ & $(0.378)$ & $(0.420)$ \\
\hline \multirow[t]{2}{*}{ Intangibles } & $1.120 * * *$ & $1.107 * *$ & -0.189 & -0.183 \\
\hline & $(0.421)$ & $(0.473)$ & $(0.333)$ & $(0.353)$ \\
\hline \multirow[t]{2}{*}{ Interest Exp } & $-18.141 * *$ & $-17.524 *$ & -1.425 & -0.766 \\
\hline & $(9.123)$ & $(9.647)$ & $(2.430)$ & $(2.766)$ \\
\hline \multirow[t]{2}{*}{ Tax Rate } & 0.100 & 0.092 & -0.010 & -0.032 \\
\hline & $(0.107)$ & $(0.111)$ & $(0.057)$ & $(0.056)$ \\
\hline \multirow[t]{2}{*}{ Change in WC } & & 0.141 & & -0.214 \\
\hline & & $(0.622)$ & & $(0.719)$ \\
\hline \multirow[t]{2}{*}{ Forecast Miss } & & 0.038 & & -0.070 \\
\hline & & $(0.117)$ & & $(0.059)$ \\
\hline \multirow[t]{2}{*}{ Forecast Error } & & -5.299 & & -1.031 \\
\hline & & $(3.584)$ & & $(3.227)$ \\
\hline \multirow[t]{2}{*}{ Cash } & $1.490 * * *$ & $1.627 * * *$ & -0.753 & -0.686 \\
\hline & $(0.413)$ & $(0.397)$ & $(0.685)$ & $(0.678)$ \\
\hline \multirow[t]{2}{*}{$R \& D$} & -0.882 & -1.098 & -1.358 & $-1.728 *$ \\
\hline & $(1.612)$ & $(1.685)$ & $(0.961)$ & $(1.014)$ \\
\hline \multirow[t]{2}{*}{ Capex } & -2.345 & -2.651 & -1.053 & -1.100 \\
\hline & $(2.732)$ & $(2.981)$ & $(1.056)$ & $(1.206)$ \\
\hline \multirow[t]{2}{*}{ Constant } & $-2.373 * * *$ & $-2.239 * * *$ & $-2.910 * * *$ & $-2.855 * * *$ \\
\hline & $(0.692)$ & $(0.709)$ & $(0.284)$ & $(0.299)$ \\
\hline Year Effects & Included & Included & Included & Included \\
\hline Observations & 38,646 & 33,659 & 38,646 & 33,659 \\
\hline Pseudo R-squared & 0.115 & 0.123 & 0.055 & 0.061 \\
\hline
\end{tabular}

Table 8 presents probit regression analyses of EBITA and EBIT disclosures for a sample of S\&P1500 firms between 2005 and 2016. The dependent variable is a dummy variable equal to one if a firm has mentioned at least one time "EBITA" (Specifications (1)-(2)) or "EBIT" (Specifications (3)-(4)) in the current year annual report (in Panel A) or in the current annual or quarterly earnings announcement (in Panel B), and zero otherwise. Annual reports and earnings announcements are extracted from EDGAR. All explanatory variables are measured for the current year. All variables are defined in the Appendix. Standard errors are presented below the coefficients in parentheses and are clustered by firm. *,**,*** denote significance at the $10 \%, 5 \%$ and $1 \%$ level (two-sided). 
Table 9: Interdependencies between EBIT, EBITA, EBITDA and Adjusted EBITDA Disclosures

Panel A: Interdependent Proportions of Disclosures

Proportion of Non - EBITDA disclosers which disclose:

Difference (p-value of T-test):

\begin{tabular}{|c|c|}
\hline (1) & Adjusted EBITDA \\
\hline (2) & EBIT or EBITA \\
\hline
\end{tabular}

Proportion of $\boldsymbol{E B I T D A}$ disclosers which also disclose:
(3)
Adjusted EBITDA
$45.89 \%$
(1) vs (3): $\mathbf{0 . 0 0 0} * * *$
(4)
EBIT or EBITA
$6.84 \%$
(2) vs (4): $\mathbf{0 . 0 8 5 *}$

Proportion of Non - Adjusted EBITDA disclosers which disclose:

\begin{tabular}{|c|c|c|}
\hline (1) & EBITDA & $7.50 \%$ \\
\hline (2) & EBIT or EBITA & $8.46 \%$ \\
\hline
\end{tabular}

Proportion of Adjusted EBITDA disclosers which disclose:
(3)
EBITDA
$36.09 \%$
(1) vs (3): $\mathbf{0 . 0 0 0 * * *}$
(4)
EBIT or EBITA
$3.54 \%$
(2) vs (4): $\mathbf{0 . 0 0 0} * * *$

Proportion of Non - EBIT or EBITA disclosers which disclose:

(1) Adjusted EBITDA $15.66 \%$

(2) EBITDA $11.89 \%$

Proportion of EBIT or EBITA disclosers which disclose:

$\begin{array}{rrrr}(3) & \text { Adjusted EBITDA } & 6.87 \% & \text { (1) vs (3): } \mathbf{0 . 0 0 0} * * * \\ \text { (4) } & \text { EBITDA } & 10.43 \% & \text { (2) vs (4): } \mathbf{0 . 0 8 5 *}\end{array}$


Panel B: Ordered Regression Specification

Dependent Variable = Sum of indicator variables indicating disclosure of Adjusted EBITDA, EBITDAR, EBITDA, EBITA and EBIT

\begin{tabular}{|c|c|c|c|c|c|c|}
\hline \multirow{3}{*}{ Sample $=$} & & \multicolumn{3}{|c|}{ in the Annual Report $(10-K)$} & \multicolumn{2}{|c|}{ in Earnings Announcements } \\
\hline & & All firms & All firms & $\begin{array}{l}\text { Only non- } \\
\text { GAAP } \\
\text { disclosing } \\
\text { Firms } \\
\end{array}$ & All firms & $\begin{array}{l}\text { Only non- } \\
\text { GAAP } \\
\text { disclosing } \\
\text { Firms } \\
\end{array}$ \\
\hline & $\begin{array}{l}\text { Predicted } \\
\text { Sign } \\
\end{array}$ & (1) & (2) & (3) & (4) & (5) \\
\hline Firm Size & - & $\begin{array}{c}-0.232 * * * \\
(0.046)\end{array}$ & $\begin{array}{c}-0.208 * * * \\
(0.050)\end{array}$ & $\begin{array}{c}-0.264 * * * \\
(0.075)\end{array}$ & $\begin{array}{c}-0.311^{* * *} \\
(0.046)\end{array}$ & $\begin{array}{c}-0.237 * * * \\
(0.072)\end{array}$ \\
\hline ROA & - & $\begin{array}{c}0.073 \\
(0.646)\end{array}$ & $\begin{array}{l}-0.749 \\
(0.884)\end{array}$ & $\begin{array}{l}-0.936 \\
(1.083)\end{array}$ & $\begin{array}{c}-2.502 * * * \\
(0.777)\end{array}$ & $\begin{array}{c}-2.979 * * \\
(1.288)\end{array}$ \\
\hline Leverage & + & $\begin{array}{c}1.009 * * * \\
(0.248)\end{array}$ & $\begin{array}{c}1.127 * * * \\
(0.298)\end{array}$ & $\begin{array}{c}0.773 * * \\
(0.375)\end{array}$ & $\begin{array}{c}1.526^{* * * *} \\
(0.258)\end{array}$ & $\begin{array}{c}0.814 * * \\
(0.364)\end{array}$ \\
\hline Market to Book & - & $\begin{array}{c}0.017 \\
(0.012)\end{array}$ & $\begin{array}{c}0.017 \\
(0.014)\end{array}$ & $\begin{array}{c}0.017 \\
(0.017)\end{array}$ & $\begin{array}{l}0.020 * \\
(0.011)\end{array}$ & $\begin{array}{c}0.008 \\
(0.015)\end{array}$ \\
\hline Sales Growth & $?$ & $\begin{array}{c}0.001 \\
(0.190)\end{array}$ & $\begin{array}{c}0.055 \\
(0.208)\end{array}$ & $\begin{array}{c}0.740 * * \\
(0.295)\end{array}$ & $\begin{array}{c}0.179 \\
(0.159)\end{array}$ & $\begin{array}{c}0.095 \\
(0.264)\end{array}$ \\
\hline Capital Intensity & + & $\begin{array}{l}0.916^{*} \\
(0.532)\end{array}$ & $\begin{array}{c}0.783 \\
(0.582)\end{array}$ & $\begin{array}{c}2.071 * * \\
(0.890)\end{array}$ & $\begin{array}{l}1.045^{* *} \\
(0.524)\end{array}$ & $\begin{array}{c}0.389 \\
(0.698)\end{array}$ \\
\hline Intangibles & + & $\begin{array}{c}1.914 * * * \\
(0.464)\end{array}$ & $\begin{array}{c}2.027 * * * \\
(0.502)\end{array}$ & $\begin{array}{c}0.350 \\
(0.745)\end{array}$ & $\begin{array}{c}2.349 * * * \\
(0.437)\end{array}$ & $\begin{array}{c}0.986 \\
(0.672)\end{array}$ \\
\hline Interest Exp & + & $\begin{array}{l}4.427 * * \\
(1.794)\end{array}$ & $\begin{array}{l}4.473 * * \\
(2.171)\end{array}$ & $\begin{array}{l}-2.392 \\
(3.051)\end{array}$ & $\begin{array}{l}3.507 * \\
(1.918)\end{array}$ & $\begin{array}{c}3.116 \\
(2.337)\end{array}$ \\
\hline Tax Rate & $?$ & $\begin{array}{l}-0.047 \\
(0.068)\end{array}$ & $\begin{array}{l}-0.036 \\
(0.074)\end{array}$ & $\begin{array}{l}-0.005 \\
(0.082)\end{array}$ & $\begin{array}{c}0.023 \\
(0.063)\end{array}$ & $\begin{array}{l}-0.093 \\
(0.085)\end{array}$ \\
\hline Change in WC & + & & $\begin{array}{l}1.461 * \\
(0.759)\end{array}$ & & $\begin{array}{c}1.870 * * * \\
(0.709)\end{array}$ & $\begin{array}{l}2.343 * \\
(1.213)\end{array}$ \\
\hline Forecast Miss & + & & $\begin{array}{c}0.024 \\
(0.063)\end{array}$ & & & \\
\hline Forecast Error & + & & $\begin{array}{l}5.082 * \\
(3.134)\end{array}$ & & & \\
\hline Cash & $?$ & $\begin{array}{c}0.411 \\
(0.584)\end{array}$ & $\begin{array}{c}0.649 \\
(0.633)\end{array}$ & $\begin{array}{c}0.006 \\
(0.986)\end{array}$ & $\begin{array}{c}1.206^{* *} \\
(0.611)\end{array}$ & $\begin{array}{c}1.452 \\
(0.884)\end{array}$ \\
\hline $\mathrm{R} \& \mathrm{D}$ & $?$ & $\begin{array}{c}-7.465^{* * *} \\
(1.371)\end{array}$ & $\begin{array}{c}-7.558 * * * \\
(1.415)\end{array}$ & $\begin{array}{c}1.330 \\
(2.548)\end{array}$ & $\begin{array}{c}-9.445^{* * *} \\
(1.354)\end{array}$ & $\begin{array}{l}-1.421 \\
(2.896)\end{array}$ \\
\hline Capex & $?$ & $\begin{array}{l}2.126^{*} \\
(1.219) \\
\end{array}$ & $\begin{array}{c}1.934 \\
(1.384) \\
\end{array}$ & $\begin{array}{l}-2.765 \\
(2.270) \\
\end{array}$ & $\begin{array}{c}3.355^{* * *} * \\
(1.214) \\
\end{array}$ & $\begin{array}{c}2.163 \\
(1.410) \\
\end{array}$ \\
\hline Year Effects & & Included & Included & Included & Included & Included \\
\hline Industry Effects & & Included & Included & Included & Included & Included \\
\hline Observations & & 10,573 & 9,038 & 2,513 & 38,643 & 9,281 \\
\hline Pseudo R-squared & & 0.119 & 0.119 & 0.111 & 0.174 & 0.136 \\
\hline
\end{tabular}


Panel C: Interdependencies between EBITDA and EBIT

\begin{tabular}{|c|c|c|c|c|c|}
\hline \multicolumn{2}{|c|}{ Dependent Variable = } & \multicolumn{2}{|c|}{$\begin{array}{l}\text { Indicator for EBITDA } \\
\text { Disclosure in 10-K }\end{array}$} & \multicolumn{2}{|c|}{$\begin{array}{l}\text { Indicator for EBITDA } \\
\text { Disclosure in earnings } \\
\text { announcements }\end{array}$} \\
\hline Subsample $=$ & & $\begin{array}{c}\text { Only firms with } \\
\text { EBIT }<0\end{array}$ & $\begin{array}{l}\text { Only firms with } \\
\text { EBITDA >0 }\end{array}$ & $\begin{array}{l}\text { Only firms with } \\
\text { EBIT }<0\end{array}$ & $\begin{array}{c}\text { Only firms with } \\
\text { EBITDA }>0\end{array}$ \\
\hline & $\begin{array}{l}\text { Pred. } \\
\text { Sign }\end{array}$ & (1) & (2) & (3) & (4) \\
\hline EBITDA Loss & - & $\begin{array}{c}-0.596 * * * \\
(0.162)\end{array}$ & & $\begin{array}{l}-0.217 * \\
(0.116)\end{array}$ & \\
\hline EBIT Loss & + & & $\begin{array}{c}0.181 \\
(0.122)\end{array}$ & & $\begin{array}{c}0.172 \\
(0.123)\end{array}$ \\
\hline Firm Size & - & $\begin{array}{c}-0.157 * * * \\
(0.061)\end{array}$ & $\begin{array}{c}-0.177 * * * \\
(0.026)\end{array}$ & $\begin{array}{c}-0.194 * * * \\
(0.062)\end{array}$ & $\begin{array}{c}-0.208 * * * \\
(0.026)\end{array}$ \\
\hline Leverage & + & $\begin{array}{c}0.610 * * \\
(0.281)\end{array}$ & $\begin{array}{c}0.665 * * * \\
(0.162)\end{array}$ & $\begin{array}{c}0.842 * * * \\
(0.245)\end{array}$ & $\begin{array}{c}0.647 * * * \\
(0.149)\end{array}$ \\
\hline Market to Book & - & & $\begin{array}{c}0.003 \\
(0.008)\end{array}$ & & $\begin{array}{l}0.005 \\
(0.006)\end{array}$ \\
\hline Sales Growth & $?$ & & $\begin{array}{c}0.086 \\
(0.110)\end{array}$ & & $\begin{array}{c}0.307 * * * \\
(0.096)\end{array}$ \\
\hline Capital Intensity & + & & $\begin{array}{c}0.555 \\
(0.350)\end{array}$ & & $\begin{array}{l}0.758 * * \\
(0.338)\end{array}$ \\
\hline Intangibles & + & & $\begin{array}{c}1.164 * * * \\
(0.296)\end{array}$ & & $\begin{array}{c}1.601 * * * \\
(0.247)\end{array}$ \\
\hline Interest Exp & + & & $\begin{array}{c}3.119 * * \\
(1.368)\end{array}$ & & $\begin{array}{c}3.156 * * * \\
(1.128)\end{array}$ \\
\hline Tax Rate & $?$ & & $\begin{array}{l}-0.038 \\
(0.039)\end{array}$ & & $\begin{array}{c}0.030 \\
(0.036)\end{array}$ \\
\hline Cash & $?$ & & $\begin{array}{c}0.106 \\
(0.365)\end{array}$ & & $\begin{array}{c}0.887 * * * \\
(0.331)\end{array}$ \\
\hline $\mathrm{R} \& \mathrm{D}$ & $?$ & & $\begin{array}{c}-4.363^{* * *} \\
(0.988)\end{array}$ & & $\begin{array}{c}-4.435^{* * *} \\
(0.752)\end{array}$ \\
\hline Capex & $?$ & & $\begin{array}{c}1.041 \\
(0.784)\end{array}$ & & $\begin{array}{c}2.143 * * * \\
(0.657)\end{array}$ \\
\hline Constant & & $\begin{array}{l}-0.017 \\
(0.497)\end{array}$ & $\begin{array}{c}-0.798^{* *} \\
(0.316)\end{array}$ & $\begin{array}{c}0.079 \\
(0.463)\end{array}$ & $\begin{array}{c}-0.615^{* *} \\
(0.285)\end{array}$ \\
\hline $\begin{array}{l}\text { Year Effects } \\
\text { Industry Effects }\end{array}$ & & $\begin{array}{l}\text { Included } \\
\text { Included }\end{array}$ & $\begin{array}{l}\text { Included } \\
\text { Included }\end{array}$ & $\begin{array}{l}\text { Included } \\
\text { Included }\end{array}$ & $\begin{array}{l}\text { Included } \\
\text { Included }\end{array}$ \\
\hline Observations & & 751 & 9,929 & 2,521 & 37,297 \\
\hline
\end{tabular}

Table 9 Panel A shows proportions of firms that disclose EBITDA, Adjusted EBITDA (Adjusted EBITDA or EBITDAR) and EBIT or EBITA (which are considered together). Differences between proportions are tested by means of T-tests. Two-sided p-values are provided in the right column. Panel B presents results from ordered logit regression analyses. The dependent variable is the sum of indicator variables for disclosure of Adjusted EBITDA, EBITDAR, EBITDA, EBITA and EBIT, ranging from 0 to 5, for a sample of S\&P1500 firms between 2005 and 2016. Specification (1) considers disclosures in the current year annual report and specification (2) in the current annual or quarterly earnings announcement. In Panel C the dependent variable EBITDA is a dummy variable equal to one if a firm has mentioned at least three times "EBITDA" in the current year annual report, and zero otherwise. EBITDA Loss is an indicator variable equal to 1 if EBITDA is negative in the current period, and zero otherwise. EBIT Loss is an indicator variable equal to 1 if EBIT is negative in the current period, and zero otherwise. In Specifications (1) and (3), only observations with a negative EBIT are considered. In Specifications (2) and (4), only observations with positive EBITDA are considered. Annual reports and earnings announcements are 
extracted from EDGAR. All explanatory variables are measured for the current year. All variables are defined in the Appendix. Standard errors are presented below the coefficients in parentheses and are clustered by firm. *,**, *** denote significance at the $10 \%, 5 \%$ and $1 \%$ level (two-sided). 